\title{
Investigation of Reactions in a Fluidized Bed Reactor during Chemical Looping combustion of Coal/Steam with Copper Oxide-Iron Oxide-Alumina Oxygen Carrier
}

Ranjani Siriwardane ${ }^{\mathrm{a}^{*}}$, William Benincosa ${ }^{\mathrm{a}, \mathrm{b}, \mathrm{c}}$, Jarrett Riley $^{\mathrm{a}, \mathrm{b}}$, Hanjing Tian ${ }^{\mathrm{a}, \mathrm{b}}$ and George Richards $^{\mathrm{a}}$

${ }^{a}$ U.S. Department of Energy, National Energy Technology Laboratory, 3610 Collins Ferry Road, P.O. Box 880, Morgantown, WV 26507-0880

${ }^{b}$ Department of Chemical Engineering, West Virginia University, Morgantown, WV 26505

${ }^{c}$ Oak Ridge Institute for Science and Education, P.O. Box 117, Oak Ridge, TN 37831

* Corresponding author:

Ranjani Siriwardane

U.S. Department of Energy

National Energy Technology Laboratory

3610 Collins Ferry Road

P.O. Box 880

Morgantown, WV 26507-0880

Tel.: + 01-304-285-4513

Fax: + 01-304-285-0903

E-mail: ranjani.siriwardane@ netl.doe.gov 


\section{ABSTRACT}

This paper presents data on conversion of two different coals with a chemical looping oxygen carrier, $\mathrm{CuO}-\mathrm{Fe}_{2} \mathrm{O}_{3}$-alumina, and over a range of conditions including steam and various levels of reduction the oxygen carrier.

Reactions of coal/steam/ CuO- $\mathrm{Fe}_{2} \mathrm{O}_{3}$-alumina oxygen carrier and coal/steam/partially reduced $\mathrm{CuO}-\mathrm{Fe}_{2} \mathrm{O}_{3}$-alumina oxygen carrier were investigated with Wyodak coal and Illinois \#6 coal in a fluidized bed reactor. Temperature programmed reaction studies indicated that the oxygen carrier enhanced the steam gasification/combustion rates of both coals. Rates of gasification/combustion were higher with Wyodak coal (sub bituminous) than that with Illinois \#6 coal (bituminous). In addition to the increase in reaction rates, the total moles of carbon that were gasified and combusted from coal/steam increased in the presence of the oxygen carrier. The reduced oxygen carrier promoted the water-gas shift reaction when reacted with synthesis gas in the presence of steam, but the reverse water gas shift reaction was observed when steam was not present. The partially reduced oxygen carrier enhanced the production of $\mathrm{H}_{2}$ from coal/steam, which was different from the observations with un-reduced oxygen carrier. Water splitting reaction to produce $\mathrm{H}_{2}$ was also observed with the reduced oxygen carrier. $\mathrm{CuO}-\mathrm{Fe}_{2} \mathrm{O}_{3}$ alumina reacted with coal during the temperature ramp to $850{ }^{\circ} \mathrm{C}$ even in the absence of steam due to the chemical-looping oxygen uncoupling (CLOU) reaction. Fourier transform infra-red (FTIR) analysis indicated the presence of volatile aromatics during the temperature ramp and these may have also contributed to the reactions with the oxygen carrier in the absence of steam. Increasing steam concentration had a negative effect on the CLOU reaction. 


\section{INTRODUCTION}

Chemical-looping combustion (CLC) is a novel combustion technology [1-8] that utilizes an oxygen carrier, such as metal oxide, to transport oxygen from the air to the fuel, thereby avoiding direct contact between fuel and air. The significant advantage of CLC over conventional combustion is that CLC can produce a storage-ready carbon dioxide $\left(\mathrm{CO}_{2}\right)$ stream—not diluted by nitrogen $\left(\mathrm{N}_{2}\right)$-without expending any major energy required for the separation of $\mathrm{CO}_{2}$. The overall CLC process, in which the metal oxide cycles between oxidized and reduced states, is exothermic.

The concept of CLC with solid fuels such as coal has been investigated extensively in the past [9-15], and progress of the CLC technology for solid fuel combustion has been presented in various review articles and books [16 -21]. Recent research work in coal CLC include oxygen carrier development [22-27] and pilot-scale demonstrations [28-41].

Fluidized bed reactor tests have been conducted to understand the reaction performance of coal CLC with various oxygen carriers. Steam is generally used to promote the initial coal gasification reaction. It is usually assumed [17] that reactions proceed through indirect reduction with the aid of gaseous intermediates. It has also been reported that coal volatiles or synthesis gas produced by steam gasification of coal may initiate the reaction with metal oxides $[13,17]$

Other researchers [42-47] have proposed a mechanism known as the chemical-looping oxygen uncoupling (CLOU) process as a method to utilize oxygen from the metal oxide decomposition for combusting solid fuel. The CLOU process was designed at temperatures at which there is substantial equilibrium partial pressure of oxygen due to decomposition of the metal oxide. The CLOU process has been demonstrated experimentally at temperatures above $800{ }^{\circ} \mathrm{C}$. 
All of the above mentioned reaction mechanisms involve gas phase intermediates. We have shown that solid-solid reactions can occur with coal and oxygen carriers when there are significant contacts between the oxygen carrier and coal [48]. When CLC is conducted in a fluidized bed reactor, the contribution from the solid-solid interaction may not be significant.

Even though several reaction mechanisms for coal CLC in a fluidized bed reactor are reported, the proposed reaction mechanisms are speculative. In addition, the oxygen carrier is continuously reduced during the reaction with coal, and the effect of partially reduced oxygen carrier on the coal/steam reaction has not been reported.

The objective of the research work reported in this paper is to identify the various reactions that could occur when coal/steam are reacted with the oxygen carrier or the partially reduced oxygen carrier in a fluidized bed reactor. The results here aim at determining which reactions are important to consider, noting that steam, the coal type, the carrier type and the extent of carrier reduction are all contributing factors. The oxygen carrier selected in this study was $\mathrm{CuO}-\mathrm{Fe}_{2} \mathrm{O}_{3}$ alumina, which has shown promising results with both methane and coal in our previous studies [49-53]. A large batch $(180 \mathrm{~kg})$ of the oxygen carrier was produced for demonstration testing in a 50-kWth chemical looping experiment, and some promising results from the pilot-scale test are also discussed. The reaction profiles of Illinois \#6 coal or Wyodak coal with and without CuO$\mathrm{Fe}_{2} \mathrm{O}_{3}$-alumina oxygen carrier over a range of conditions including steam and various levels of oxygen reduction are reported in the current study. 


\section{EXPERIMENTAL}

\subsection{Oxygen carriers}

\begin{tabular}{|c|c|}
\hline Particle Sphericity & $0.79-0.94$ \\
\hline Particle Density & $3.13 \mathrm{~g} / \mathrm{cm}^{3}$ \\
\hline Bulk Density (Fluffed) & $1.32 \mathrm{~g} / \mathrm{cm}^{3}$ \\
\hline Void Fraction (Fluffed) & 0.58 \\
\hline Bulk Density (Packed) & $0.24 \mathrm{~g} / \mathrm{cm}^{3}$ \\
\hline Void Fraction & 0.53 \\
\hline Density measured by He Pycnometer & $4.66 \mathrm{~g} / \mathrm{cm}^{3}$ \\
\hline Tapped Density & $1.45 \mathrm{~g} / \mathrm{cm}^{3}$ \\
\hline Particle Size & $74-250 \mu \mathrm{m}$ \\
\hline
\end{tabular}

Table 1. Physical Properties of Copper Ferrite Oxygen Carrier

$\mathrm{CuO}-\mathrm{Fe}_{2} \mathrm{O}_{3}$-alumina oxygen carriers (52) were prepared using the commercial spray drying method at Nextech Inc. The composition of the oxygen carrier was 30 wt. \% $\mathrm{CuO}, 30$ wt. $\% \mathrm{Fe}_{2} \mathrm{O}_{3}$, and $40 \mathrm{wt} . \%$ alumina, and the particle size range was $74-250 \mu \mathrm{m}$. The material properties of the oxygen carrier are listed in Table 1.

\subsection{Coal characterization}

The compositions of the two coals, Wyodak and Illinois \#6, are listed in Table 2. Illinois 6 coal, which is a bituminous coal has the highest carbon value and lowest volatile matter.

Wyodak coal is a subbituminous coal and has higher volatile matter.

\begin{tabular}{|l|l|l|l|l|l|l|l|l|}
\hline Coal Type & $\begin{array}{c}\text { Particle } \\
\text { Size }\end{array}$ & Class & $\begin{array}{c}\text { Ash } \\
(\text { dry })\end{array}$ & $\begin{array}{c}\text { S } \\
(\text { dry })\end{array}$ & $\begin{array}{c}\text { C } \\
(\mathrm{dmmf})\end{array}$ & $\begin{array}{c}\text { H } \\
(\mathrm{dmmf})\end{array}$ & $\begin{array}{c}\text { V.M. } \\
(\mathrm{dmmf})\end{array}$ & $\begin{array}{c}\mathrm{kJ} / \mathrm{kg} \\
(\mathrm{dmmf})\end{array}$ \\
\hline Wyodak & $74-300 \mu \mathrm{m}$ & $\mathrm{hvCb}$ & 16.2 & 4.52 & 81.8 & 5.7 & 43.8 & 33857 \\
\hline Illinois \#6 & $74-300 \mu \mathrm{m}$ & subB & 7.6 & 0.43 & 76.2 & 6.2 & 48.1 & 30789 \\
\hline
\end{tabular}

Table 2. Properties of Coals 


\subsection{Temperature programmed reaction studies with coal in fluidized bed reactor tests}

Minimum fluidization velocities (MFV) of $\mathrm{CuO}-\mathrm{Fe}_{2} \mathrm{O}_{3}$-alumina oxygen carriers at various temperatures are listed in Table 3. The temperature programmed reaction (TPR) studies were carried out using a fluidized bed reactor manufactured by Autoclave Engineers HR-160 Reactor Assembly (Model \# 5010-2377/HR-160). The oxygen carrier/coal bed height was $7.62 \mathrm{~cm}$, and the diameter was $6 \mathrm{~cm}$. The reactor column was made from Inconel SB-564 to withstand temperatures up to $900{ }^{\circ} \mathrm{C}$. A ceramic porous plate with $15-40 \mu \mathrm{m}$ pores was used as the gas distributor. The setup is equipped with three electrical heaters installed around the reactor to heat the reactor to the target temperature of $850{ }^{\circ} \mathrm{C}$. Prior to the tests, $10 \mathrm{~g}$ each of coal and $322 \mathrm{~g} \mathrm{CuO}-\mathrm{Fe}_{2} \mathrm{O}_{3}$-alumina oxygen carriers were mixed. Then the mixture was heated from $25{ }^{\circ} \mathrm{C}$ to $850{ }^{\circ} \mathrm{C}$ at a heating rate of $4{ }^{\circ} \mathrm{C} / \mathrm{min}$ in helium at a flow rate of 7.8 SLPM $(24 \mathrm{x}$ MFV of $\mathrm{Fe}-\mathrm{Cu}$ /alumina at $850{ }^{\circ} \mathrm{C}$ ). Then the sample was maintained at $850 \mathrm{C}$ for 0.5 hours in helium. During the experiments, 30 vol. \% steam was introduced either during the temperature ramp beginning at $300{ }^{\circ} \mathrm{C}$ or after the isothermal dwell at $850{ }^{\circ} \mathrm{C}$. After the reudicng reaction with coal, the sample was cooled to 750 ${ }^{\circ} \mathrm{C}$ to initiate oxidation with air for 1.5 hours. The reactor effluent was monitored using a Pfeiffer Omnistar mass spectrometer. All the experiments were repeated and reproducibility has been excellent.

\begin{tabular}{|c|c|}
\hline Temperature $\left({ }^{\circ} \mathrm{C}\right)$ & $\begin{array}{c}\text { Minimum Fluidization Velocity } \\
\text { (SLPM) }\end{array}$ \\
\hline 25 & 3.16 \\
\hline 624 & 0.8 \\
\hline 750 & 0.63 \\
\hline 800 & 0.4 \\
\hline 900 & 0.25 \\
\hline
\end{tabular}

Table 3. Minimum fluidization velocity of the copper ferrite oxygen carrier with temperature dependence

\subsection{Diffuse reflectance Fourier transform infrared spectroscopy}

Prior to use, the as-received coal samples were ground into a powder to maximize spectral quality via diffuse reflectance infrared fourier transform spectroscopy (DRIFTS) analysis. For each test, a coal sample of approximately $20 \mathrm{mg}$ was charged to a DRIFTS reactor cell (Thermo Electron product 0031- 
902). The DRIFTS cell is a cold-walled reactor that features temperature control and ZnSe windows for IR transmission within the $650-4000 \mathrm{~cm}-1$ range. Helium was introduced to the coal sample to remove all the gases from the cell. Then the Helium flow was stopped and sample was heated from ambient to 800 ${ }^{\circ} \mathrm{C}$. Infrared spectra were collected at various temperatures with a Thermo-Nicolet Nexus 670 FTIR instrument, which housed the DRIFTS reactor cell. Spectra were collected at a resolution of $4 \mathrm{~cm}-1$ with 50 co-added scans using a liquid N2-cooled MCT/A detector.

\section{RESULTS AND DISCUSSION}

When coal is reacted with an oxygen carrier in the presence of steam, various reactions can take place and some possible reactions are listed below.

- Coal gasification and subsequent gas reactions with oxygen carrier:

$$
\begin{aligned}
& \mathrm{C}+\mathrm{H}_{2} \mathrm{O} \quad \rightarrow \quad \mathrm{CO}+\mathrm{H}_{2} \quad \Delta \mathrm{H}_{800}=135.74 \mathrm{~kJ} / \mathrm{mol} \\
& \mathrm{H}_{2}+\text { Metal oxide } \rightarrow \text { Reduced metal oxide }+\mathrm{H} 2 \mathrm{O} \\
& \mathrm{CO}+\text { Metal oxide } \rightarrow \quad \text { Reduced metal oxide }+\mathrm{CO}_{2} \text { (3) } \\
& \mathrm{C}+\mathrm{CO}_{2} \rightarrow \quad 2 \mathrm{CO} \quad \Delta \mathrm{H}_{800}=169.44 \mathrm{~kJ} / \mathrm{mol}
\end{aligned}
$$

- Chemical looping oxygen un-coupling (CLOU) mechanism :

$$
\begin{aligned}
& 4 \mathrm{CuO} \rightarrow 2 \mathrm{Cu}_{2} \mathrm{O}+\mathrm{O}_{2} \quad \text { (5) } \Delta \mathrm{H}_{800}=67.8 \mathrm{~kJ} / \mathrm{mol} \\
& \mathrm{C}+\mathrm{O}_{2} \rightarrow \mathrm{CO}_{2} \quad \text { (6) } \Delta \mathrm{H}_{800}=-395 \mathrm{~kJ} / \mathrm{mol}
\end{aligned}
$$

- Solid-solid interaction: $\mathrm{MeO}+\mathrm{C} \rightarrow \mathrm{Me}+\mathrm{CO}_{2}$ (7)

- Water-gas shift (WGS) reaction catalyzed by reduced oxygen carrier:

$$
\mathrm{CO}+\mathrm{H}_{2} \mathrm{O} \rightarrow \mathrm{CO}_{2}+\mathrm{H}_{2} \quad \Delta \mathrm{H}_{800}=-33.07 \mathrm{~kJ} / \mathrm{mol}
$$


- Reduced oxygen carrier oxidation by steam:

$$
2 \mathrm{FeO}+\mathrm{H}_{2} \mathrm{O} \rightarrow \mathrm{Fe}_{2} \mathrm{O}_{3}+\mathrm{H}_{2} \quad \Delta \mathrm{H}=-31.9 \mathrm{~kJ} / \mathrm{mol}
$$

\subsection{Steam gasification of coal without an oxygen carrier with steam at $300-850^{\circ} \mathrm{C}$}

In order to understand the coal gasification process with steam, as shown in reaction 1, $30 \%$ steam was introduced during the temperature ramp of coal without the oxygen carrier. Figure 1 shows the effluent gas concentrations during the temperature ramp of the two coals with steam and a comparative plot of cumulative moles of each gas produced. The comparative plot also displays the $\mathrm{CO}_{2}$ produced during the oxidation segment of the experiments $\left(\mathrm{PO} \mathrm{CO}_{2}\right)$ which was also included in the cumulative carbon balances. The steam gasification process appears to initiate around $600{ }^{\circ} \mathrm{C}$ with concentration peaks around $850{ }^{\circ} \mathrm{C}$ with both coals. The rate of steam gasification was significantly higher with Wyodak coal than that with Illinois \#6 coal as indicated by the $\mathrm{CO}$ and $\mathrm{H}_{2}$ peak maxima in Figure 1. The $\mathrm{H}_{2}, \mathrm{CO}$ and $\mathrm{CO}_{2}$ peaks for Illinois \#6 coal were very broad, slow continuous gas production was observed when the temperature was maintained at $850{ }^{\circ} \mathrm{C}$, which was different from Wyodak coal. Wyodak coal, which is a sub-bituminous coal had a higher rate of production of synthesis gas with steam than Illinois \#6 coal, which is a high rank coal as also shown in Figure 1. It has been reported [55-58] that the properties of the char can affect the combustion performance. The char produced by Illinois \#6 coal may have different properties than that produced by Wyodak coal and may have contributed to the different reaction rates and product distributions. Char porosity and surface area have shown to play an important role on the gasification reaction [57, 58], and differences in char type affected the gasification rates as seen in figure 1. It was reported that [57, 58] Wyodak coal has thermoset type char while Illinois \#6 has thermoplastic type. The plastic coals like Illinois \#6 are known to form chars with highly cellular pore structure, while non-plastic coals do 
not undergo drastic macro pore structural changes during the pyrolysis stage. Scanning electron micrographs of Wyodak coal char and Ilinois \#6 coal char are reported in Figure 2 and it is clear that the surface morphologies of the two chars are different. Char from Illinois \#6 coal had a smoother surface with some voids while the char from Wyodak coal appeared to have a rough surface. These differences in the surface morphology may also have contributed to the different char gasification rates. Even though the gasification rates were different, the cumulative moles of gases produced during gasification were very similar with the two coals, as shown in Figure 1. Total moles of carbon from steam gasification followed by oxidation for Wyodak and Illinois \#6 coals were 0.3 and 0.4 , respectively. Illinois \#6 has a higher carbon value than Wyodak coal, thus the data is consistent. In addition to the gasification products, the data indicated that the type of coal plays a major role in the steam gasification rates as well.

\subsection{Effect of $\mathrm{CuO}-\mathrm{Fe}_{2} \mathrm{O}_{3}$-alumina oxygen carrier on coal/steam (300-850 $\left.{ }^{\circ} \mathrm{C}\right)$ interactions}

Figure 3 shows effluent gas compositions when coal and $\mathrm{CuO}-\mathrm{Fe}_{2} \mathrm{O}_{3}$-alumina was heated in the presence of $30 \%$ vol. steam from $300-850^{\circ} \mathrm{C}$ and cumulative moles of gas produced. Repeated experiments characterizing the interaction between three components, coal, steam, and oxygen carrier, showed excellent reproducibility as also demonstrated in Figure 3. In the experiments containing Wyodak coal, steam, and oxygen carrier, repeated runs reproduced the carbon dioxide peak concentrations by a difference of $0.4 \%$, the total carbon molar production by $1.2 \%$, and the full width half maximum of the major carbon dioxide peak concentrations by $3.2 \%$ and $3.3 \%$. For the interaction between Illinois \#6, steam, and oxygen carrier, repeated experiments reproduced the carbon dioxide peak concentrations by a difference of $4.5 \%$, the total carbon molar production by $2.8 \%$ and the full width half maximum of the major $\mathrm{CO} 2$ 
concentration peak by $2.8 \%$ and $11.0 \%$. It should be noted that all results reported in this paper were verified by repeating the experiments, and all results were reproducible as such.

The concentration peak of $\mathrm{CO}_{2}$ was significantly higher than the concentration peaks of $\mathrm{H}_{2}$ and $\mathrm{CO}$, with both coals indicating the faster reaction of synthesis gas derived from coal with the oxygen carriers to produce $\mathrm{CO}_{2}$. The concentration peak of $\mathrm{CO}_{2}$ with Wyodak coal was higher than that with Illinois \#6 coal, indicating faster reaction rate with Wyodak coal. The reaction with Wyodak coal also takes place at a lower temperature than that with Illinois \#6 coal which also indicated better reactivity of Wyodak coal. Cumulative moles of gases produced during the temperature ramp, also shown in Figure 3, indicated that the amount of $\mathrm{CO}_{2}$ produced as well as the total carbon gases $\left(\mathrm{CO}\right.$ and $\left.\mathrm{CO}_{2}\right)$ formed were similar with Illinois \#6 coal and Wyodak coal. Thus, the total carbon combusted with both coals by the oxygen carrier were similar even though the rates of gasification and combustion were lower with Illinois \#6 coal.

Comparative data on outlet gas concentrations during the temperature ramps in the presence of steam at $300-850{ }^{\circ} \mathrm{C}$ with Wyodak coal/steam/CuO- $\mathrm{Fe}_{2} \mathrm{O}_{3}$-alumina, and Wyodak coal/steam (blank) are shown in Figure 4. The $\mathrm{CO}_{2}$ peak concentration was higher, and the peak temperature was lower when the oxygen carrier was present with coal/steam, which indicated that rate production of $\mathrm{CO}_{2}$ was faster when the oxygen carrier is present. The amount of $\mathrm{H}_{2}$ produced from steam gasification of coal was significantly higher with blank Wyodak coal than that with coal/oxygen carrier due to the consumption of $\mathrm{H}_{2}$ by the oxygen carrier. During the temperature ramp of Wyodak coal/steam/CuO-Fe ${ }_{2} \mathrm{O}_{3}$-alumina, the decrease in peak intensity of $\mathrm{H}_{2}$ was more significant than that with $\mathrm{CO}$ indicating the faster consumption of $\mathrm{H}_{2}$ from coal gasification by the oxygen carrier. 
The cumulative gas products formed are also shown in Figure 4. The total amount of CO and $\mathrm{CO}_{2}$ produced with coal/steam/ CuO-Fe $2 \mathrm{O}_{3}$-alumina was higher than that with coal/steam, indicating that there was additional carbon oxide formation due to the presence the oxygen carrier. Since $\mathrm{H}_{2} \mathrm{O}$ formed was not measured during the reaction, it was not possible to obtain an accurate measurement of the amount of oxygen utilized from the oxygen carrier for the reaction with hydrogen. A rough estimate was made using the cumulative data in Figure 3: The quantity of hydrogen produced during coal/steam gasification was 0.38 moles and it decreased to 0.15 moles with coal/steam/oxygen carrier due to the consumption of $\mathrm{H}_{2}$ by the oxygen carrier. The consumption of $\mathrm{H}_{2}$ by the oxygen carrier was about 0.23 moles, assuming that there was no additional $\mathrm{H}_{2}$ formed when the oxygen carrier was present with coal/steam and the consumption of $\mathrm{CO}$ was about 0.03 moles and the increase in $\mathrm{CO}_{2}$ was 0.18 moles. The increase in the $\mathrm{CO}_{2}$ does not correlate well with the decrease in $\mathrm{CO}$, indicating that there was additional $\mathrm{CO}_{2}$ formed by the increase in gasification/combustion due to the presence of the oxygen carrier. Thus, the presence of the oxygen carrier not only improves the gasification rate, but it also increases the total carbon gasified. Saucedo et al. [25] reported that the presence of $\mathrm{Fe}_{2} \mathrm{O}_{3}$ led to an increase in the rate of gasification because of the rapid oxidation of $\mathrm{CO}$ by the oxygen carrier to $\mathrm{CO}_{2}$ within the mass transfer boundary layer surrounding the char particle. This effect was most prominent when the surface area of the char was at its maximum due to the accompanying increase in porosity and pore size during the char gasification. Other researchers $[26,54]$ have also observed an increase in coal gasification rates in the presence of oxygen carriers.

Comparative data on outlet gas concentrations during the temperature ramps (steam 300$850{ }^{\circ} \mathrm{C}$ ) with Illinois \#6 coal/steam/ $\mathrm{CuO}-\mathrm{Fe}_{2} \mathrm{O}_{3}$-alumina, and Illinois \#6 coal/steam (blank) are 
shown in Figure 5. When the oxygen carrier was present $\mathrm{H}_{2}$ was consumed at a faster rate, $\mathrm{CO}$ was produced at an increased rate and there was a rapid increase in the $\mathrm{CO}_{2}$ production rate. The total carbon oxides produced was higher when the oxygen carrier was present than that without the oxygen carrier, as also shown in Figure 5, indicating that there was more carbon gasification/combustion ( 0.18 moles) when the oxygen carrier was present. The $\mathrm{H}_{2}$ decreased about 0.33 moles, $\mathrm{CO}_{2}$ increased about 0.19 moles, while the change in $\mathrm{CO}$ was insignificant (0.01). Similar to the data above with Illinois \#6 coal, $\mathrm{CuO}-\mathrm{Fe}_{2} \mathrm{O}_{3}$ oxygen carrier promoted additional coal gasification/combustion with Wyodak coal as well.

\subsection{Effect of steam on the interaction of synthesis gas derived from steam gasification of coal with $\mathrm{CuO}-\mathrm{Fe}_{2} \mathrm{O}_{3}$-alumina oxygen carrier}

When the synthesis gas derived from steam gasification (reactions 2 and 3) of coal reacts with the oxygen carrier, the reaction performance may be affected by the presence of steam. In order to understand this effect, synthesis gas was reacted with the oxygen carrier in the presence of various concentrations of steam. Simulated synthesis gas composition was $\mathrm{H}_{2}$ : $7.6 \%(36.8$ $\mathrm{mmol} / \mathrm{min}), \mathrm{CO}_{2}: 1.88 \%(9.1 \mathrm{mmol} / \mathrm{min}), \mathrm{CO}: 1.58 \%(7.7 \mathrm{mmol} / \mathrm{min})$ in helium. Steam concentrations of 0,15 and $30 \%$ were introduced to the synthesis gas during the temperature ramps with the oxygen carrier, and effluent gas compositions were measured.

The outlet gas compositions during the reaction of synthesis gas and $\mathrm{CuO}-\mathrm{Fe}_{2} \mathrm{O}_{3}$-alumina oxygen carrier are shown in Figure 6. The data indicated that $\mathrm{CO}$ and $\mathrm{H}_{2}$ were consumed and $\mathrm{CO}_{2}$ was generated during the temperature ramp due to the reaction of synthesis gas with the oxygen carrier. Steam has a significant effect on the reaction. After the initial reduction of the oxygen carrier, the effluent concentrations of the gases were strongly affected by the concentration of steam. When steam was present, $\mathrm{CO}$ concentration was lower than the initial 
concentration while $\mathrm{H}_{2}$ and $\mathrm{CO}_{2}$ were higher. The data indicated that the water-gas shift reaction (8) was catalyzed by the reduced oxygen carrier when steam was present to consume CO to produce $\mathrm{CO}_{2}$ and $\mathrm{H}_{2}$. Since steam is also consumed by the coal to produce synthesis gas, it is difficult to estimate the extent of the water-gas shift reaction by the reduced oxygen carrier in the in the coal/steam/oxygen carrier system since steam is also consumed for the coal gasification reaction.

It was also interesting to note that when steam was not present, after the initial reaction with oxygen carrier the $\mathrm{CO}$ concentration was higher than the initial concentration while the $\mathrm{H}_{2}$ and $\mathrm{CO}_{2}$ were lower. It appears that the reduced oxygen carrier was promoting the reverse water gas shift reaction (10) when steam was not present.

$$
\mathrm{CO}_{2}+\mathrm{H}_{2} \rightarrow \mathrm{CO}+\mathrm{H}_{2} \mathrm{O}
$$

The increase in $\mathrm{CO}$ when steam was not present could also be due to the reaction of $\mathrm{CO}_{2}$ with the reduced oxygen carrier $(\mathrm{M})$ to form $\mathrm{CO}$ as shown in reaction (11)

$$
\mathrm{M}+\mathrm{CO}_{2} \rightarrow \mathrm{CO}+\mathrm{MO}
$$

In order to understand this reaction, the oxygen carrier was reduced first with synthesis gas $\left(\mathrm{CO}_{2} 2.02 \%, \mathrm{CO} 6.41 \%, \mathrm{H} 210.24 \%\right.$, and $\left.\mathrm{He} 81.22\right)$, and then $28 \% \mathrm{CO}_{2}$ in helium was introduced at $800{ }^{\circ} \mathrm{C}$. Formation of $\mathrm{CO}$ (results not shown) was not observed indicating that the reverse water-gas shift reaction (10) is the most possible explanation for the formation of additional CO when steam was not present. Repeated experiments showed similar results.

\subsection{Interaction of coal/steam with reduced $\mathrm{CuO}-\mathrm{Fe}_{2} \mathrm{O}_{3}$-alumina oxygen carrier.}


During the reaction of the oxygen carrier with coal/steam, the oxygen carrier is continuously reduced. The reduced carrier may have an effect on the initial coal gasification reaction with steam (reaction 1). In order to understand how the reduced carrier affects the reaction, the $\mathrm{CuO}-\mathrm{Fe}_{2} \mathrm{O}_{3}$-alumina oxygen carrier was reduced to various reduction states with methane and then the reduced oxygen carrier was mixed with coal, and temperature ramp was performed in the presence of steam.

\begin{tabular}{|c|c|c|c|}
\hline $\begin{array}{c}\text { Reduction } \\
\text { Time }\end{array}$ & $\begin{array}{c}\text { Experimental } \\
\text { Oxygen Transfer } \\
\text { Capacity }\end{array}$ & Reduction Reaction & $\begin{array}{c}\text { Theoretical } \\
\text { Oxygen Transfer } \\
\text { Capacity }\end{array}$ \\
\hline 5.5 Minutes & $5.5 \%$ & $4 \mathrm{CuO}+\mathrm{CH}_{4} \rightarrow 4 \mathrm{Cu}+\mathrm{CO}_{2}+2 \mathrm{H}_{2} \mathrm{O}$ & $6.0 \%$ \\
\hline & & & $7.0 \%$ \\
\hline 7 Minutes & $7.0 \%$ & $3 \mathrm{CuO}+3 \mathrm{Fe}_{2} \mathrm{O}_{3}+\mathrm{CH}_{4} \rightarrow 3 \mathrm{Cu}+2 \mathrm{Fe}_{3} \mathrm{O}_{4}+\mathrm{CO}_{2}+2 \mathrm{H}_{2} \mathrm{O}$ & \\
\hline & & & $9.0 \%$ \\
\hline 12 Minutes & $8.0 \%$ & $3 \mathrm{CuO}+\mathrm{Fe}_{2} \mathrm{O}_{3}+\mathrm{CH}_{4} \rightarrow 3 \mathrm{Cu}+2 \mathrm{FeO}+\mathrm{CO}+2 \mathrm{H}_{2} \mathrm{O}$ & \\
\hline
\end{tabular}

Table 4. Reduction States of copper and iron at various reduction times

Oxygen transfer capacities were calculated using equation (12). Experimental oxygen transfer capacity is based on the effluent gaseous products and the theoretical oxygen transfer capacity is based on the corresponding chemical reaction.

Oxygen Transfer Capacity $=\frac{[\mathrm{Mol} \mathrm{CO2*2Mol} \mathrm{O+Mol} \mathrm{H} 2 \mathrm{O} * 1 \mathrm{Mol} \mathrm{O}] * 16.0 \mathrm{~g} / \mathrm{mol}}{\text { Mass Oxygen Carrier }}$

The reduced states of the oxygen carrier estimated from the percentage of oxygen transfer during the reaction with methane are listed in Table 4. The gas compositions during the temperature ramp with Wyodak coal/reduced oxygen carrier/steam and comparative data with the unreduced oxygen carrier are shown in Figure 7. The $\mathrm{CO}_{2}$ concentration peak was highest and both $\mathrm{CO}$ and $\mathrm{H}_{2}$ concentration peaks were lowest with the unreduced oxygen carrier, indicating the highest rate of combustion because more oxygen atoms are available for the 
reaction with coal or synthesis gas. With increased reduction of the oxygen carrier, the rate of $\mathrm{CO}_{2}$ production decreased and rate of $\mathrm{CO}$ and $\mathrm{H}_{2}$ production increased since less oxygen atoms are available for the reaction with synthesis gas. Repeated experiments showed similar results.

The cumulative moles of gases produced are also shown in Figure 7. It is interesting to note that amount of $\mathrm{H}_{2}$ continuously increased with increased reduction of the oxygen carrier while there was no significant changes in the amounts of $\mathrm{CO}$ and $\mathrm{CO}_{2}$. The cumulative carbon oxides $\left(\mathrm{CO}+\mathrm{CO}_{2}\right)$ produced were similar with the reduced and un-reduced oxygen carriers. Even after reduction there were oxygens still available from the oxygen carrier for the reactions. However, it appears that total production of $\mathrm{CO}$ to $\mathrm{CO}_{2}$ was not greatly affected by the oxygen carrier reduction, but the production of $\mathrm{H}_{2}$ was affected.

A comparison of the effluent gas compositions of coal/steam without the oxygen carrier, with the unreduced oxygen carrier, and reduced oxygen carrier (12 min) are shown in Figure 8. It is interesting to note that both $\mathrm{CO}$ and $\mathrm{H}_{2}$ concentration peaks were highest with the reduced carrier/coal/steam than that with coal/steam without an oxygen carrier. It should also be noted that the concentration peaks of both $\mathrm{CO}$ and $\mathrm{H}_{2}$ with reduced carrier/coal/steam were shifted to a lower temperature than that with coal/steam without the oxygen carrier. The data indicated that the reduced oxygen carrier was either promoting the coal gasification reaction rate or changing the reaction pathway. It has been reported that coal gasification reaction can be promoted by reduced iron oxide, but it is not clear how the reduced oxygen carrier promotes the gasification reaction in the fluidized bed reactor. Alkali incorporated $\mathrm{Fe}_{2} \mathrm{O}_{3}$ also has shown improved gasification of coal [22] in a fluid bed reactor but the reason for the improvement is not known. The cumulative product gas yields are also shown in Figure 8. It is clear that the $\mathrm{H}_{2}$ yield was 
higher with the reduced oxygen carrier/coal/steam than that with coal/steam, indicating that in addition to improving reaction rates, total moles of $\mathrm{H}_{2}$ were also higher with the reduced oxygen carrier/coal/steam. Total CO produced with the reduced oxygen carrier/coal/steam was similar to that with coal/steam but the amount of $\mathrm{CO}_{2}$ formed was higher with the reduced oxygen carrier. However, the increase in $\mathrm{H}_{2}$ (0.33 moles) was higher than the increase in $\mathrm{CO}_{2}(0.13$ moles $)$.

If the water-gas shift reaction is promoted by the reduced oxygen carrier there should be a corresponding increase in $\mathrm{CO}_{2}$ similar to the $\mathrm{H}_{2}$ increase and a decrease in the amount of $\mathrm{CO}$. A small increase in $\mathrm{CO}_{2}$ was observed with oxygen carrier/coal/steam as compared to that with coal/steam, but the change in the amount of $\mathrm{CO}$ was insignificant, indicating that the increase in $\mathrm{H}_{2}$ with reduced oxygen carrier/coal/steam cannot be explained by the water-gas shift reaction. Since steam is consumed for the coal gasification reaction, the remaining steam concentration in the gas stream may not be adequate for promoting the water-gas shift reaction.

It is possible that in addition to the reaction (1), $\mathrm{H}_{2}$ formation facilitated by the water splitting reaction (9) may also be occurring in the presence of reduced oxygen carrier.

\subsection{Interaction of reduced $\mathrm{CuO}-\mathrm{Fe}_{2} \mathrm{O}_{3}$-alumina carrier with steam}

In order to understand the $\mathrm{H}_{2} \mathrm{O}$ splitting reaction by the reduced oxygen carrier to produce $\mathrm{H}_{2}$ by reaction (9), the oxygen carrier was first reduced with methane for 5.5 min., 7 min. and 12 min. to obtain different oxidation states, and then a temperature ramp was conducted in the presence of $30 \%$ steam without coal.

As shown in Figure 9, $\mathrm{H}_{2}$ concentration increased with increasing reduction of the oxygen carrier but the $\mathrm{H}_{2}$ concentration was below 0.12 vol. \%. Repeated experiments show similar results. The increase in $\mathrm{H}_{2}$ production rate and total moles with the reduced oxygen 
carrier/coal/steam in Figure 8, cannot be fully explained by this water splitting reaction since the contribution is low. The reaction of steam with the reduced $\mathrm{Fe}^{0} / \mathrm{Fe}^{+2}$ is favorable (19), while it is not favorable with $\mathrm{Cu}^{0}$. Thus, the contribution may be only due to the iron component in the oxygen carrier. However, this reaction may be enhanced when the coal is present due to the consumption of oxygen by carbon to form $\mathrm{CO}_{2}$.

\subsection{Effect of addition of steam at $850^{\circ} \mathrm{C}$ on the reaction of $\mathrm{CuO}-\mathrm{Fe}_{2} \mathrm{O}_{3}$-alumina with coal}

In order to understand the effect of steam addition temperature, Wyodak coal/ $\mathrm{CuO}$ $\mathrm{Fe}_{2} \mathrm{O}_{3}$-alumina was heated to $850{ }^{\circ} \mathrm{C}$ without steam and $30 \%$ steam was added at $850{ }^{\circ} \mathrm{C}$. The results are shown in Figure 10. For comparison, the data with Wyodak coal/ $\mathrm{CuO}-\mathrm{Fe}_{2} \mathrm{O}_{3}-$ alumina/steam addition at $300{ }^{\circ} \mathrm{C}$ and a blank data of Wyodak coal/steam addition at $850{ }^{0} \mathrm{C}$ without the oxygen carrier are also shown in Figure 10. During the initial temperature ramp of coal without steam to $850{ }^{0} \mathrm{C}$, only minute amounts of $\mathrm{H}_{2}, \mathrm{CO}$, and $\mathrm{CO}_{2}$ were observed but high concentration peaks of $\mathrm{H}_{2}, \mathrm{CO}$, and $\mathrm{CO}_{2}$ were observed when steam was introduced at $850{ }^{0} \mathrm{C}$. The $\mathrm{H}_{2}, \mathrm{CO}$, and $\mathrm{CO}_{2}$ concentration peaks when steam was introduced at $850{ }^{\circ} \mathrm{C}$ to coal were higher than that when steam was introduced at 300-800 ${ }^{\circ} \mathrm{C}$ (Figure 1), indicating fast gasification rates at $850{ }^{\circ} \mathrm{C}$ as expected.

The product gases when Wyodak coal/ $\mathrm{CuO}-\mathrm{Fe}_{2} \mathrm{O}_{3}$-alumina was heated in the absence of steam up to $850{ }^{\circ} \mathrm{C}$ and during steam addition at $850{ }^{\circ} \mathrm{C}$ are also shown in Figure 10. It is interesting to note that the $\mathrm{CO}_{2}$ concentration peak was high during the temperature ramp even in the absence of steam. This is possibly due to coal directly reacting with the oxygen released from the $\mathrm{CuO}$ via CLOU reactions (5) and (6). The $\mathrm{CO}_{2}$ peak solely due to the reaction of coal with oxygen from CLOU reaction was at a higher temperature than that with Wyodak coal/ CuO$\mathrm{Fe}_{2} \mathrm{O}_{3}$-alumina/steam $300-850{ }^{0} \mathrm{C}$, indicating that synthesis gas from coal steam gasification 
react with the oxygen carrier at a lower temperature than the CLOU oxygen/coal reaction temperature. There was also a $\mathrm{CO}$ peak during the temperature ramp without steam. The concentration peaks of both $\mathrm{CO}_{2}$ and $\mathrm{CO}$ for Wyodak coal/ $\mathrm{CuO}-\mathrm{Fe}_{2} \mathrm{O}_{3}$-alumina/steam at $850{ }^{0} \mathrm{C}$, were lower than that with Wyodak coal/ $\mathrm{CuO}-\mathrm{Fe}_{2} \mathrm{O}_{3}$-alumina/steam at $300-850{ }^{\circ} \mathrm{C}$ because some coal has already reacted with the oxygen released from the oxygen carrier via CLOU reaction prior to the introduction of steam at $850{ }^{\circ} \mathrm{C}$. The best $\mathrm{CO}_{2}$ production rate and the highest $\mathrm{CO}_{2}$ amounts were observed when steam was introduced at $300{ }^{0} \mathrm{C}$ during the temperature ramp due to the combination of CLOU and gasification/combustion/CLOU reactions occurring simultaneously at $700-800{ }^{\circ} \mathrm{C}$.

Comparative data on outlet gas concentrations during the temperature ramps with Illinois \#6 coal/steam at $300-850{ }^{\circ} \mathrm{C} / \mathrm{CuO}-\mathrm{Fe}_{2} \mathrm{O}_{3}$-alumina, Illinois \#6 coal/steam at $850{ }^{\circ} \mathrm{C}$ base line, and Illinois \#6 coal/CuO-Fe $2 \mathrm{O}_{3}$-alumina-with steam at $850{ }^{\circ} \mathrm{C}$ are shown in Figure 11 . When steam was introduced at $850{ }^{\circ} \mathrm{C}$ to Illinois \#6 coal, the production of $\mathrm{H}_{2}$ and $\mathrm{CO}$ was not complete after 90 mins. When the oxygen carrier was present with coal/steam at $850{ }^{\circ} \mathrm{C}$, both $\mathrm{CO}$ and $\mathrm{CO}_{2}$ peak concentrations increased, indicating faster gasification of carbon and rapid reaction of $\mathrm{CO}$ to produce $\mathrm{CO}_{2}$ in the presence of the oxygen carrier. During the temperature ramp of Illinois coal/ $\mathrm{CuO}-\mathrm{Fe}_{2} \mathrm{O}_{3}$-alumina without steam, the $\mathrm{CO}_{2}$ peak was low, indicating minimal contribution from the CLOU reaction of $\mathrm{CuO}-\mathrm{Fe}_{2} \mathrm{O}_{3}$ oxygen carrier with Illinois \#6 coal, which was different from the observations with Wyodak coal. Oxygen released from the oxygen carrier was not able to react readily with Illinois \#6, which is not a sub-bituminous coal like Wyodak coal. The differences in coal char properties of the two coals may have contributed to the differences in reactivities with oxygen. When steam was present during the temperature ramp, there was a 
significant increase in $\mathrm{CO}_{2}$ and some increase in $\mathrm{CO}$ indicating that $\mathrm{CuO}-\mathrm{Fe}_{2} \mathrm{O}_{3}$-alumina oxygen carrier promoted both carbon gasification and subsequent reaction to form $\mathrm{CO}_{2}$.

The amounts of gases produced are also shown in Figure 11. Total carbon produced during steam gasification at $850{ }^{\circ} \mathrm{C}$ was 0.37 moles, which is lower than $(0.45$ moles $)$ when oxygen carrier was present, indicating that the oxygen carrier promoted more gasification of carbon. The $\mathrm{CO}_{2}$ produced during the temperature ramp to $850 \mathrm{C}$ with oxygen carrier was about 0.17 , moles which is possibly due to the oxygen release from $\mathrm{CuO}$.

\subsection{Diffuse reflectance infrared spectroscopic analysis (DRIFTS)}

During the temperature ramp even without steam, the oxygen carrier reacted with coal to produce a substantial amount of $\mathrm{CO}_{2}$. This production is more pronounced with Wyodak coal than with Illinois \#6 coal. In addition to the reaction of gaseous oxygen produced by CLOU from the oxygen carrier, it is also possible that other volatile hydrocarbons were produced during the heating of the coals that reacted with either the oxygen carrier or the $\mathrm{O}_{2}$ from CLOU. When the two coals were heated in a thermogravimetric analyzer (TGA) from ambient to $900{ }^{\circ} \mathrm{C}$, in Argon weight losses (data not shown) were observed with both coals. The TGA weight loss from ambient to $500{ }^{\circ} \mathrm{C}$ with Illinois \#6 coal and Wyodak coal were 25.72 wt. $\%$ and 37.88 wt. \%, respectively. These weight losses may be due to coal devolatalization and are consistent with the data obtained during the fluidized test. During the TGA temperature ramp from $500-850{ }^{\circ} \mathrm{C}$, weight loss with Illinois \#6 was 11.48 wt. \%, while it was 13.63 wt. \% with Wyodak coal. Even though there was weight loss at $500-850{ }^{\circ} \mathrm{C}, \mathrm{H}_{2}$ and $\mathrm{CO}$ was not detected in this temperature range when coal was heated without steam during the temperature ramp in the fluidized bed. 
Diffuse reflectance infrared spectroscopic (DRIFTS) analysis was conducted to understand the formation of these gaseous species/volatiles during the temperature ramp with both Wyodak and Illinois \#6 coals. A Coal/quartz sample was placed in the DRIFTS cell, and the system was flushed with helium to remove any residual air. Then the helium flow was terminated, and the sample was heated in helium remained in the cell while recording FTIR spectra at various temperatures.

The results with Wyodak coal at various temperatures are shown in Figure 12. Peaks corresponding to aromatic C-H stretching at 2850, 2921 and $3014 \mathrm{~cm}^{-1}$ appeared around $325{ }^{\circ} \mathrm{C}$ and continued to grow when the temperature was increased to $625^{\circ} \mathrm{C}$. The data indicated that other volatile hydrocarbon species continued to form when the temperature was increased. The $\mathrm{CO}_{2}$ peaks that were observed when Wyodak coal was heated with $\mathrm{CuO}-\mathrm{Fe}-\mathrm{Al}$ carrier may also be due to these hydrocarbons reacting with the oxygen carrier in addition to the reaction of oxygens directly with coal. However, it is difficult to quantify the hydrocarbon yields and the extent of the reactions with the oxygen carrier. Similar observations were observed with Illinois \#6 coal as shown in Figure 13.

\subsection{Effect of steam on CLOU}

In order to understand how the oxygen uncoupling reaction from the / $\mathrm{CuO}-\mathrm{Fe}_{2} \mathrm{O}_{3}$-alumina oxygen carrier was affected by the presence of steam, a temperature ramp was conducted with $\mathrm{CuO}-\mathrm{Fe}_{2} \mathrm{O}_{3}$-alumina oxygen carrier in the presence of $0 \%, 15 \%$ and $30 \%$ steam and the oxygen concentration from the effluent gas stream was analyzed during the temperature ramp.

As shown in Figure 14, with increasing steam concentration, ion current corresponding to oxygen decreased, indicating a decrease in oxygen production with increasing steam concentration. The data indicated that presence of steam is not favorable for the oxygen un- 
coupling process, which is consistent with the data reported previously (59). Steam has also been reported to be unfavorable for the reaction of synthesis gas with the oxygen carriers (60).

Based on the data reported in this paper, the reactions that occur during the temperature ramp with coal/ $\mathrm{CuO}-\mathrm{Fe}_{2} \mathrm{O}_{3}$-alumina oxygen carrier/steam are summarized in Figure 15.

\section{CONCLUSIONS}

The steam gasification/combustion rates of both Wyodak and Illinois \#6 coals were faster in the presence of the $\mathrm{CuO}-\mathrm{Fe}_{2} \mathrm{O}_{3}$-alumina oxygen carrier. In addition to the increase in reaction rates, the total moles carbon oxides $\left(\mathrm{CO}+\mathrm{CO}_{2}\right)$ formed from coal/steam were higher in the presence of the oxygen carrier. Gasification/combustion rates were faster with the subbituminous Wyodak coal than that with bituminous Illinois \#6 coal. Reactions with simulated steam derived synthesis gas indicated that reduced oxygen carrier promoted the water-gas shift reaction when steam was present, while reverse water-gas shift reaction was promoted when steam was not present. The total amount of hydrogen production and rate of $\mathrm{H}_{2}$ production increased when the partially reduced oxygen carrier reacted with coal/steam compared to either coal/steam or coal/steam/oxidised oxygen carrier. The main products with reduced oxygen carrier /coal/steam were $\mathrm{H}_{2}$ and $\mathrm{CO}_{2}$, which were different from the observations with unreduced oxygen carrier. Water splitting reaction to produce $\mathrm{H}_{2}$ was also observed with the reduced oxygen carrier. When steam was added at $850{ }^{\circ} \mathrm{C}$, the coal gasification rates were faster than when steam was added at $300{ }^{0} \mathrm{C} . \mathrm{CuO}-\mathrm{Fe}_{2} \mathrm{O}_{3}$-alumina reacted with coal during the temperature ramp to $850{ }^{\circ} \mathrm{C}$ even in the absence of steam due to the CLOU reaction. CLOU reaction was found to be negatively affected by the increasing steam concentration. FTIR data 
indicated that volatile aromatic and aliphatic hydro carbons continued to increase during the temperature ramp from 325 to $625{ }^{0} \mathrm{C}$.

\section{ACKNOWLEDGEMENTS}

This research was supported in part by an appointment to the National Energy Technology Laboratory Research Participation Program, sponsored by the U.S. Department of Energy and administered by the Oak Ridge Institute for science and education.

\section{REFERENCES}

1. Ishida M, Zheng D, Akehata T. Evaluation of a chemical-looping-combustion powergeneration system by graphic exergy analysis. Energy 1987;12:147-154.

2. Hatanaka T, Matsuda S, Hatano H. IECEC-97: proceedings of the thirty-second intersociety energy conversion engineering conference. Honolulu, Hawaii, 1997;1:944-948. 
3. Richter HJ, Knoche KF. Reversibility of combustion process. ACS Symposium Series 1983;235:71-85.

4. Ishida M, Jin H. A novel combustor based on chemical-looping reactions and its reaction kinetics. Journal of Chemical Engineering of Japan 1994;27:296-301.

5. Anheden M, Svedberg G. Exergy analysis of chemical looping combustion systems. Energy Conversion Management 1998;39:1967-1980.

6. Diego LF, Garcia-Labiano F, Adanez J, Gayan P, Abad A, Corbella BM, Palacios JM. Development of $\mathrm{Cu}$-based oxygen carriers for chemical-looping combustion. Fuel 2004;83:1749-1757.

7. Garcia-Labiano F, Adanez J, Diego LF, Gayan P, Abad A. Effect of Pressure on the behavior of copper-, iron, and nickel-based oxygen carriers for chemical-looping combustion. Energy \& Fuels 2006;20:26-33.

8. Gupta P, Velazquez-Vargas LG, Fan LS. Syngas redox (SGR) process to produce hydrogen from coal derived syngas. Energy \& Fuels 2007;21:2900-2908.

9. Kronberger B, Lyngfelt A, Loffler G, Hofbauer H. Design and fluid dynamic analysis of a bench-scale combustion system with $\mathrm{CO}_{2}$ separation- chemical-looping combustion. Industrial \& Chemistry Research 2005;44:546-556.

10. M. Ishida, Jin H. Yokohma, United States Patent No. 5447,024, 2005. Bcbdgf

11. Shen L, Wu J, Xiao J, Song Q, Xiao R. Chemical looping combustion of biomass in a 10 kWth reactor with iron oxide as an oxygen carrier. Energy Fuels 2009;23:2498-2505.

12. Siriwardane R, Tian H, Richards G, Simonyi T, Poston J. Chemical-looping combustion of coal with metal oxide oxygen carriers. Energy and Fuels 2009;23:3885-3892. 
13. Cao Y, Casenas B, Pan W. Investigation of chemical looping combustion of solid fuels. Energy and Fuels 2006;20:1845-1854.

14. Lyon RK, Cole JA. Unmixed combustion: An alternative to fire. Combustion and Flame. 2000;121:249-261.

15. Scott SA, Dennis JS, HayHurst AN, Brown T. In situ gasification of a solid fuel and $\mathrm{CO}_{2}$ Separation using chemical looping. American Institute of Chemical Engineers. 2006;52:3325-3328.

16. Lyngfelt A, Johansson M, Mattisson T. Chemical looping combustion status and development. $9^{\text {th }}$ International conference on circulating fluidized beds, May13-16, 2008, Hamburg, Germany.

17. Adanez J, Abad A, Garcia-Labiano F, Gayan P, Diego L. Progress in Chemicals-looping combustion and reforming technologies. Progress in Energy and Combustion Science 2012;38:215-282.

18. Lyngfelt, A. Chemical looping combustion of solid fuels - Status and development. Applied Energy 2014;113:1869-1873.

19. Fan LS. Chemical looping systems for fossil energy conversions. John Wiley and Sons Inc.; 2010.

20. Anthony EJ. Solid looping cycles: a new technology for coal conversion. Industrial \& Engineering Chemistry Research 2008;47:1747-1754.

21. Henderson C. Chemical looping combustion of coal. IEA Clean Coal Center; 2010.

22. Ge H, Shen L, Gu H, Jiang S. Effect of co-precipitation and impregnation on K-decorated Fe2O3/A12O3 oxygen carrier in Chemical Looping Combustion of bituminous coal. Chemical Engineering Journal 2015;262:1065-1076. 
23. Arjmand M, Leion H, Mattisson T, Lyngfelt A. Investigation of different manganese ores as oxygen carriers in chemical-looping combustion (CLC) for solid fuels. Applied Energy 2014;113:1883-1894.

24. Mendiara T, Diego L, García-Labiano F, Gayán P, Abad A, Adánez J. On the use of a highly reactive iron ore in Chemical Looping Combustion of different coals. Fuel 2014;126: 239249.

25. Saucedo M, Lim J, Dennis J, Scott S. CO2-gasification of a lignite coal in the presence of an iron-based oxygen carrier for chemical-looping combustion. Fuel 2014;127:186-201.

26. Yang W, Zhao H, Ma J, Mei D, Zheng C. Copper-Decorated Hematite as an Oxygen Carrier for in Situ Gasification Chemical Looping Combustion of Coal. Energy \& Fuels Energy Fuels 2014;28:3970-3981.

27. Fan Y, Siriwardane R. Novel New Oxygen Carriers for Chemical Looping Combustion of Solid Fuels. Energy \& Fuels Energy Fuels 2014;28:2248-2257.

28. Abad A, Adánez J, Gayán P, Diego L, García-Labiano F, Sprachmann G. Conceptual design of a 100MWth CLC unit for solid fuel combustion. Applied Energy 2015;157:462-474.

29. Abad A, Pérez-Vega R, Diego L, García-Labiano F, Gayán P, Adánez J. Design and operation of a 50kWth Chemical Looping Combustion (CLC) unit for solid fuels. Applied Energy 2015;157:295-303.

30. Bayham S, McGiveron O, Tong A, Chung E, Kathe M, Wang D, Zeng L, Fan LS. Parametric and dynamic studies of an iron-based 25-kWth coal direct chemical looping unit using subbituminous coal. Applied Energy 2015;145:354-363.

31. Lyngfelt A, Leckner B. A 1000MWth boiler for chemical-looping combustion of solid fuels - Discussion of design and costs. Applied Energy 2015;154:475-487. 
32. Ma J, Zhao H, Tian X, Wei Y, Rajendran S, Zhang Y, Bhattacharya S, Zheng C. Chemical looping combustion of coal in a 5kWth interconnected fluidized bed reactor using hematite as oxygen carrier. Applied Energy 2015;157:304-313.

33. Ohlemüller P, Alobaid F, Gunnarsson A, Ströhle J, Epple B. Development of a process model for coal chemical looping combustion and validation against 100kWth tests. Applied Energy 2015;157:433-448.

34. Ströhle J, Orth M, Epple B. Chemical looping combustion of hard coal in a 1 MWth pilot plant using ilmenite as oxygen carrier. Applied Energy 2015;157:288-294.

35. Adánez J, Abad A, Perez-Vega R, Diego L, García-Labiano F, Gayán P. Design and Operation of a Coal-fired $50 \mathrm{kWth}$ Chemical Looping Combustor. Energy Procedia 2014;63:63-72.

36. Linderholm C, Knutsson P, Schmitz M, Markström P, Lyngfelt A. Material balances of carbon, sulfur, nitrogen and ilmenite in a 100kW CLC reactor system. International Journal of Greenhouse Gas Control 2014;27:188-202.

37. Luo S, Bayham S, Zeng L, Mcgiveron O, Chung E, Majumder A, Fan L. Conversion of metallurgical coke and coal using a Coal Direct Chemical Looping (CDCL) moving bed reactor. Applied Energy 2014;118:300-308.

38. Markström P, Linderholm C, Lyngfelt A. Operation of a 100kW chemical-looping combustor with Mexican petroleum coke and Cerrejón coal. Applied Energy 2014;113:1830-1835.

39. Ströhle J, Orth M, Epple B. Design and operation of a 1MWth chemical looping plant. Applied Energy 2014;113:1490-1495. 
40. Thon A, Kramp M, Hartge E, Heinrich S, Werther J. Operational experience with a system of coupled fluidized beds for chemical looping combustion of solid fuels using ilmenite as oxygen carrier. Applied Energy 2014;118:309-317.

41. Tong A, Bayham S, Kathe M, Zeng L, Luo S, Fan L. Iron-based syngas chemical looping process and coal-direct chemical looping process development at Ohio State University. Applied Energy 2014;113:1836-1845.

42. Mattison T, Lyngfelt A, Leion L. Chemical looping with oxygen uncoupling for combustion of solid fuels. International Journal of Greenhouse Gas Control 2009;3:11-19.

43. Coppola A, Solimene R, Bareschino P, Salatino P. Mathematical modeling of a two-stage fuel reactor for chemical looping combustion with oxygen uncoupling of solid fuels. Applied Energy 2015;157:449-461.

44. Dansie J, Sahir A, Hamilton M, Lighty J. An investigation of steam production in chemicallooping combustion (CLC) and chemical-looping with oxygen uncoupling (CLOU) for solid fuels. Chemical Engineering Research and Design 2015;94:12-17.

45. Peltola P, Ritvanen J, Tynjälä T, Hyppänen T. Fuel reactor modelling in chemical looping with oxygen uncoupling process. Fuel 2015;147:184-194.

46. Sahir A, Dansie J, Cadore A, Lighty J. A comparative process study of chemical-looping combustion (CLC) and chemical-looping with oxygen uncoupling (CLOU) for solid fuels. International Journal of Greenhouse Gas Control 2014;22:237-243.

47. Adánez-Rubio I, Arjmand M, Leion H, Gayán P, Abad A, Mattisson T, Lyngfelt A. Investigation of combined supports for $\mathrm{Cu}$-based oxygen carriers for chemical looping with oxygen uncoupling (CLOU). Energy Fuels 2013;27:3918-3927. 
48. Siriwardane R, Tian H, Miller D, Richards G, Simonyi T, Poston J. Evaluation of reaction mechanism of coal-metal oxide interactions in chemical-looping combustion. Combustion and Flame 2010;157:2198-2208.

49. Siriwardane R, Ksepko E, Tian T, Poston J, Simonyi T, Sciazko M. Interaction of ironcopper mixed metal oxide oxygen carriers with simulated synthesis gas derived from steam gasification of coal. Applied Energy 2013;107:111-23.

50. Siriwardane R, Tian H, Simonyi T, Poston J. Synergetic effects of mixed copper-iron oxides oxygen carriers in chemical looping combustion. Fuel 2013;108:319-33.

51. Monazam ER, Breault RW, Tian H, Siriwardane R. Reaction kinetics of mixed CuO-Fe2O3 with methane as oxygen carriers for chemical looping combustion. Industrial \& Engineering Chemistry Research 2015;54:11966-11974.

52. Siriwardane S, Tian H, Miller D, Richards G. Fluidized bed testing of commercially prepared $\mathrm{MgO}$-promoted hematite and $\mathrm{CuO}-\mathrm{Fe}_{2} \mathrm{O}_{3}$ mixed metal oxide oxygen carriers for methane and coal chemical looping combustion. Applied Energy 2015;157:348-357.

53. Siriwardane R, Tian H, Fisher J. Production of pure hydrogen and synthesis gas with $\mathrm{Cu}-\mathrm{Fe}$ oxygen carriers using combined processes of chemical looping combustion and methane decomposition/reforming. International Journal of Hydrogen Energy 2015;40:1698-1708.

Gasification faster in the presence of OC

54. Leon H, Jerndal E, Steenari BM, Hermansson S, Israelsson M, Jansson E, Johnsson M, Thunberg T, Vadenbo A, Mattisson T, Lyngfelt A. Solid Fuels in chemical looping combustion using oxide scale and unprocessed iron ore as oxygen carriers. Fuel 2009;88: 1945-1954. 
55. Bao J, Li Z, Cai N. Experiments of char particle segregation effect on the gas conversion behavior in the fuel reactor for chemical looping combustion. Applied Energy 2014;113:1874-1882.

56. Chen L, Liu F, Heather SN, Fan Z, Liu K. Coal char-fueled chemical looping combustion use different iron- based oxygen carriers. Energy Procedia 2014;63:5172-5177.

57. Kulaots I, Hsu A, Suuberg EM. The role of porosity in char combustion. Proceedings of the Combustion Institute 2007:31;1897-1903.

58. Zygourakis K. The effects of pyrolysis conditions on the macropore structure of coal chars. Preprints of Papers- American Chemical Society, Division of Fuel Chemistry 1988;33:951959.

59. Zhang Y, Liu F, Chen L, Han C, Richurg LR, Neathery JK, Liu K. Investigation of the water vapor influence on the performance of iron-, copper-, and nickel-based oxygen carriers for chemical looping combustion. Energy \& Fuels 2013;27:5341-5351.

60. Rubel AM, Zhang Y, Neathery JK, Lui K. Effect of water vapor on the redox reactions of iron based oxygen carriers for chemical looping combustion. Energy \& Fuels 2011;25:4271-4279. 

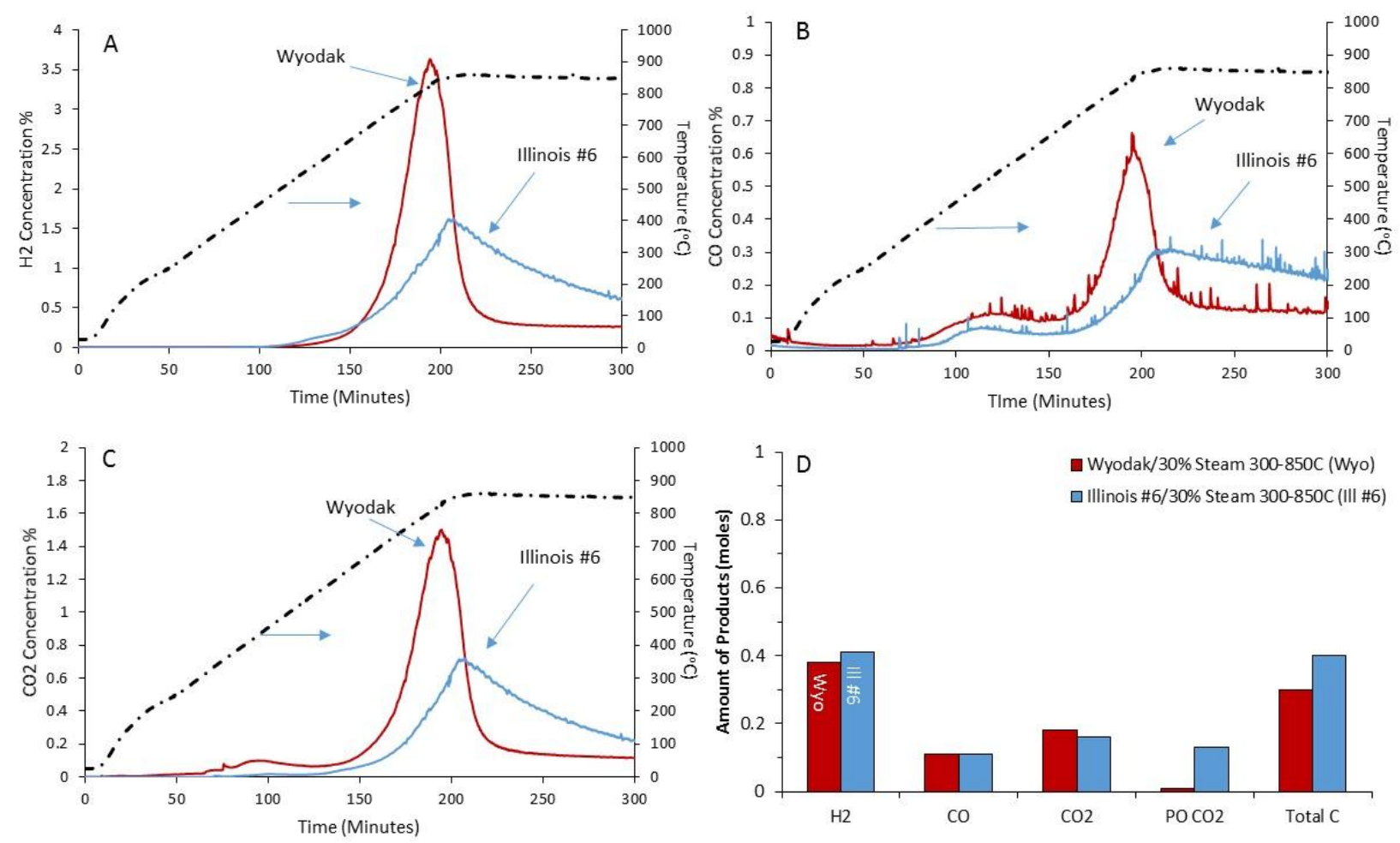

Figure 1. Product gas composition during the temperature ramp $\left(\mathrm{RT}-850^{\circ} \mathrm{C}\right)$ of Wyodak and Illinois \#6 coal in the presence of steam $\left(300-850^{\circ} \mathrm{C}\right)$, without an oxygen carrier (A) H2 (B) CO (C) CO2 (D) Total Molar Production of Gases 


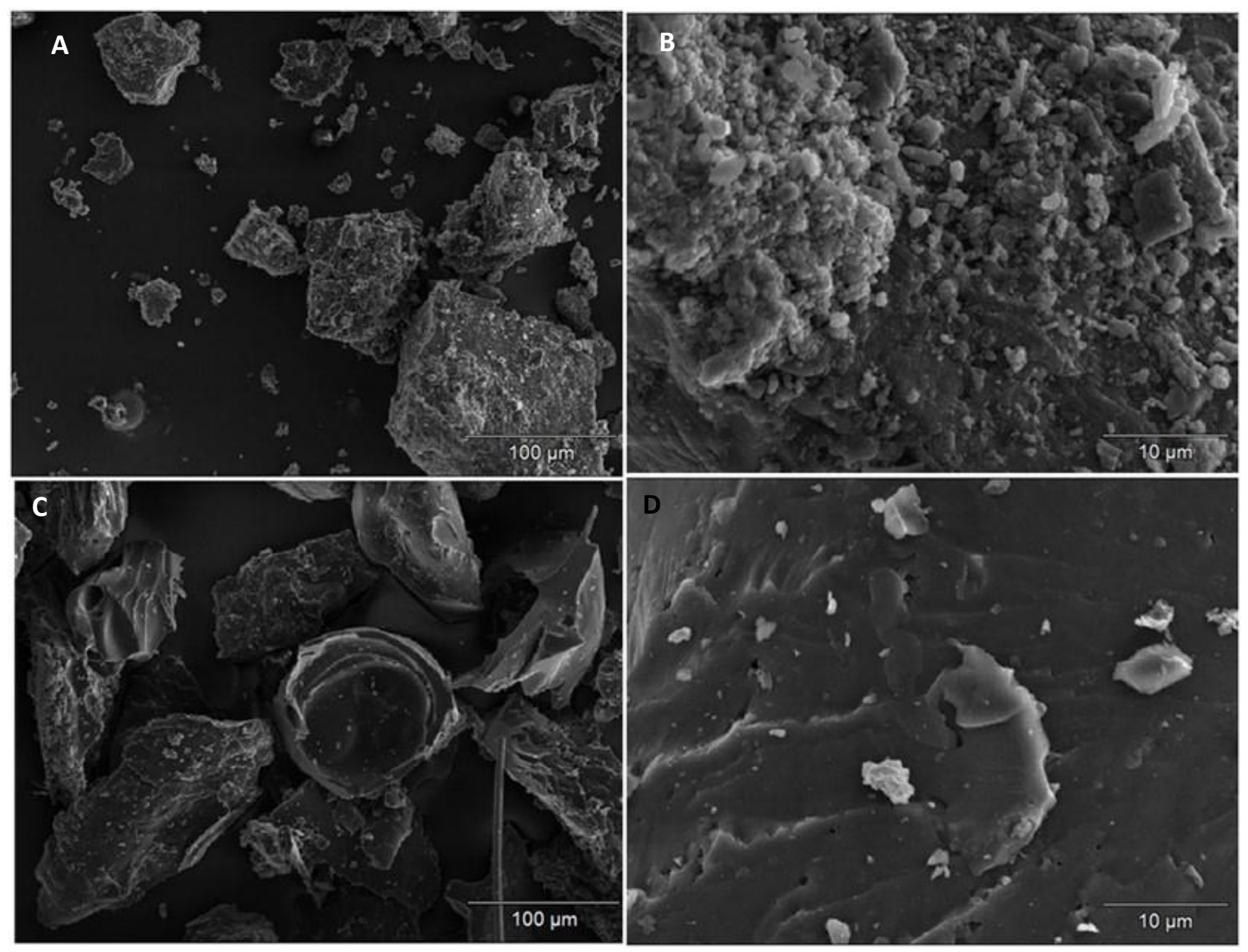

Figure 2. Scanning electron micrographs of Wyodak (A,B) and Illinois \#6 (C,D) coal chars at two different magnifications. 

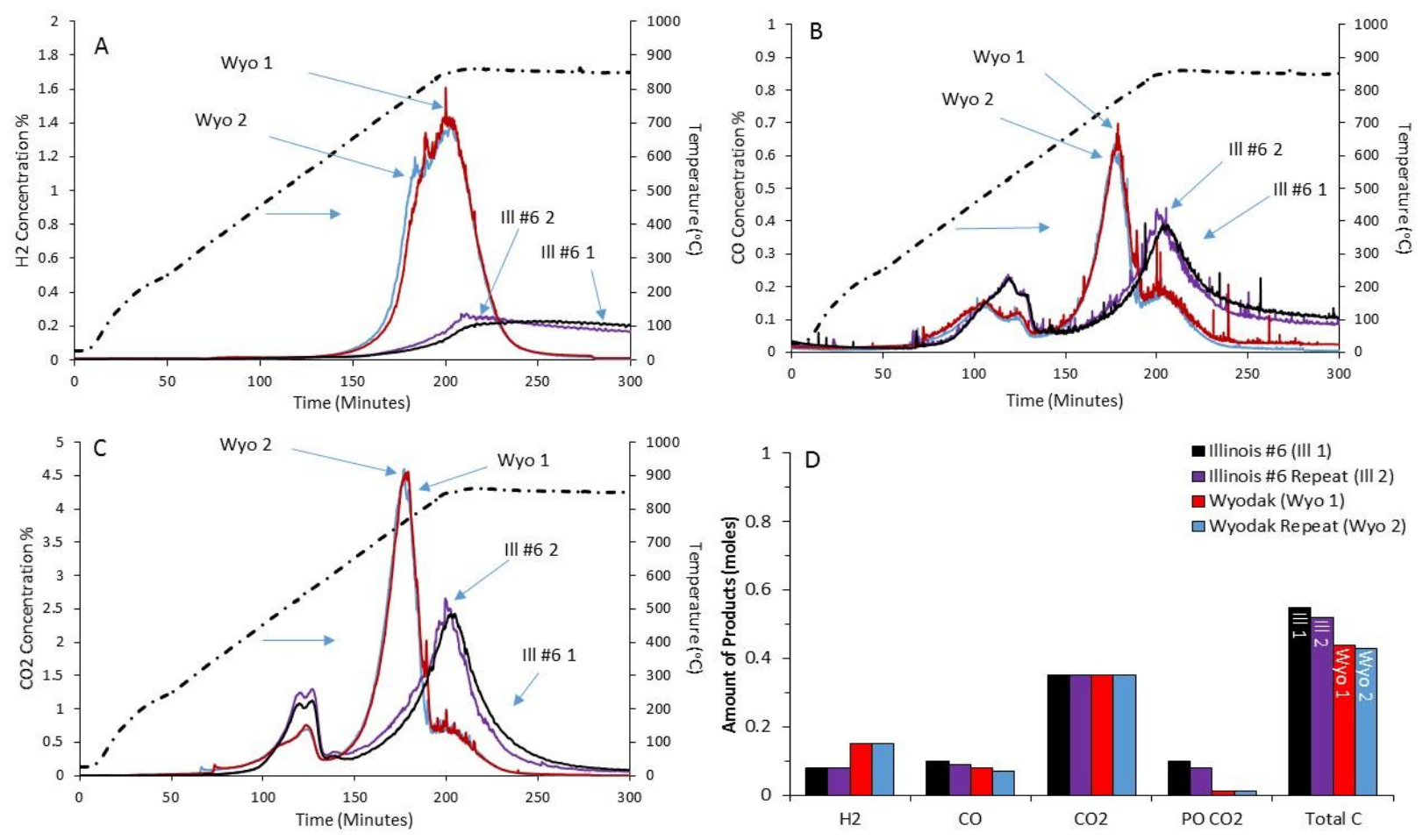

Figure 3. Reproducibility of product gas composition during the temperature ramp $\left(\mathrm{RT}-850^{\circ} \mathrm{C}\right)$ of Wyodak or Illinois \#6 coal in the presence of steam $\left(300-850^{\circ} \mathrm{C}\right)$ and copper ferrite oxygen carrier (A) $\mathrm{H} 2$ (B) $\mathrm{CO}$ (C) $\mathrm{CO} 2$ (D) Total Molar Production of Gases 

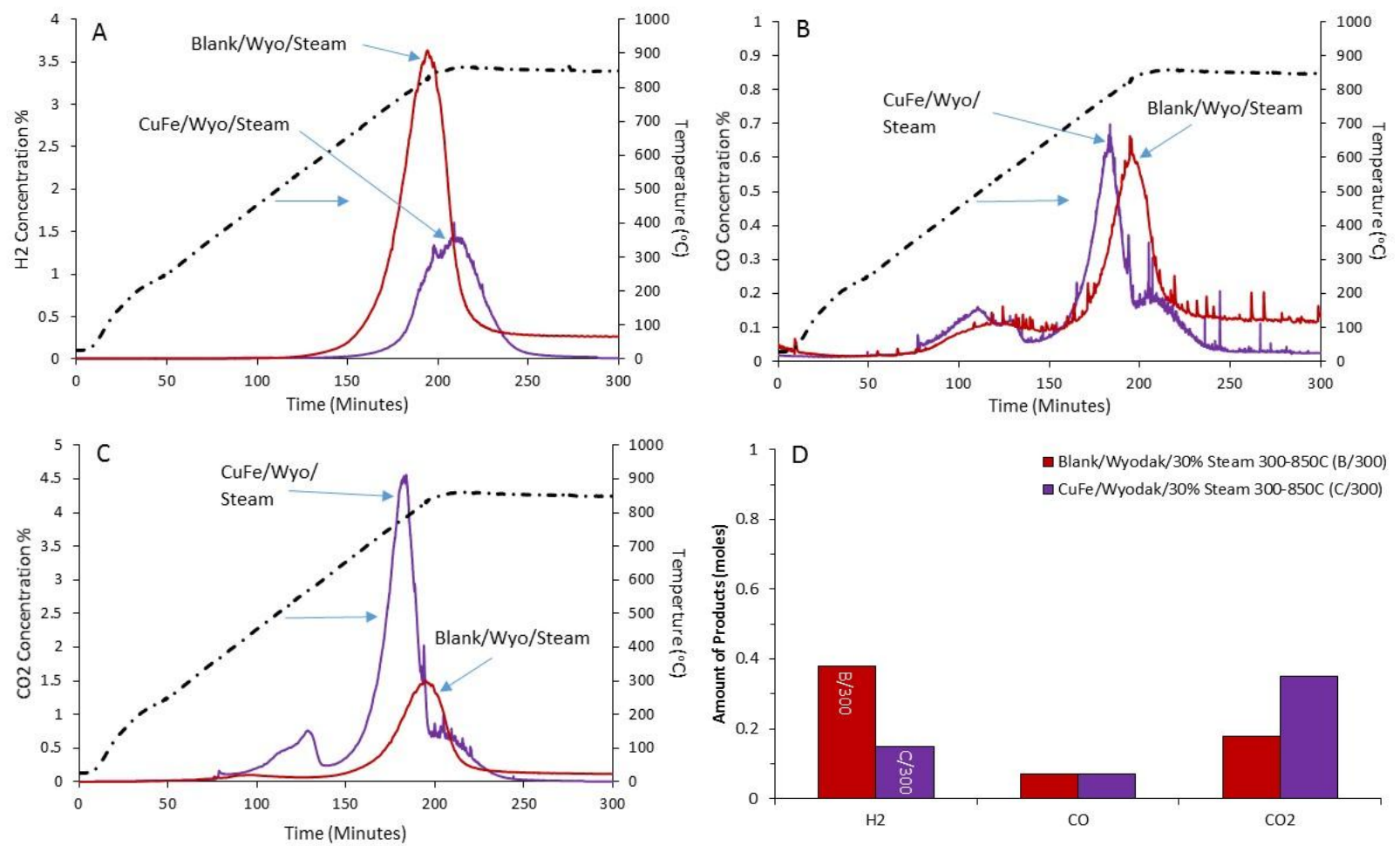

Figure 4. Product gas composition during the temperature ramp $\left(\mathrm{RT}-850^{\circ} \mathrm{C}\right)$ of Wyodak coal in the presence of steam $\left(300-850^{\circ} \mathrm{C}\right.$ ) or the copper ferrite oxygen carrier (A) $\mathrm{H} 2$ (B) $\mathrm{CO}$ (C) $\mathrm{CO} 2$ (D) Total Molar Production of Gases 

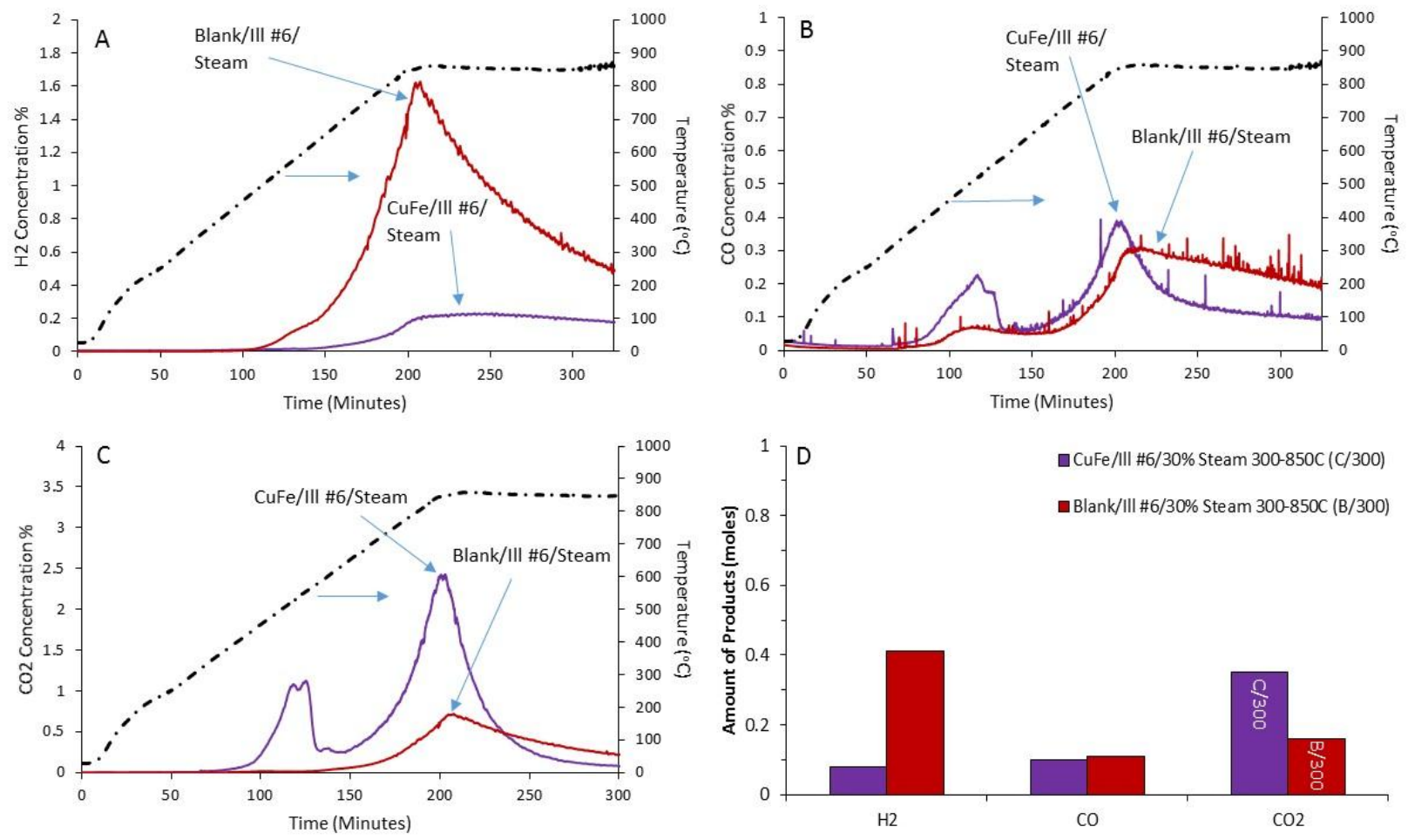

Figure 5. Product gas composition during the temperature ramp $\left(\mathrm{RT}-850^{\circ} \mathrm{C}\right)$ of Illinois $\# 6$ coal in the presence of steam $\left(300-850^{\circ} \mathrm{C}\right)$ or the copper ferrite oxygen carrier (A) H2 (B) CO (C) CO2 (D) Total Molar Production of Gases 

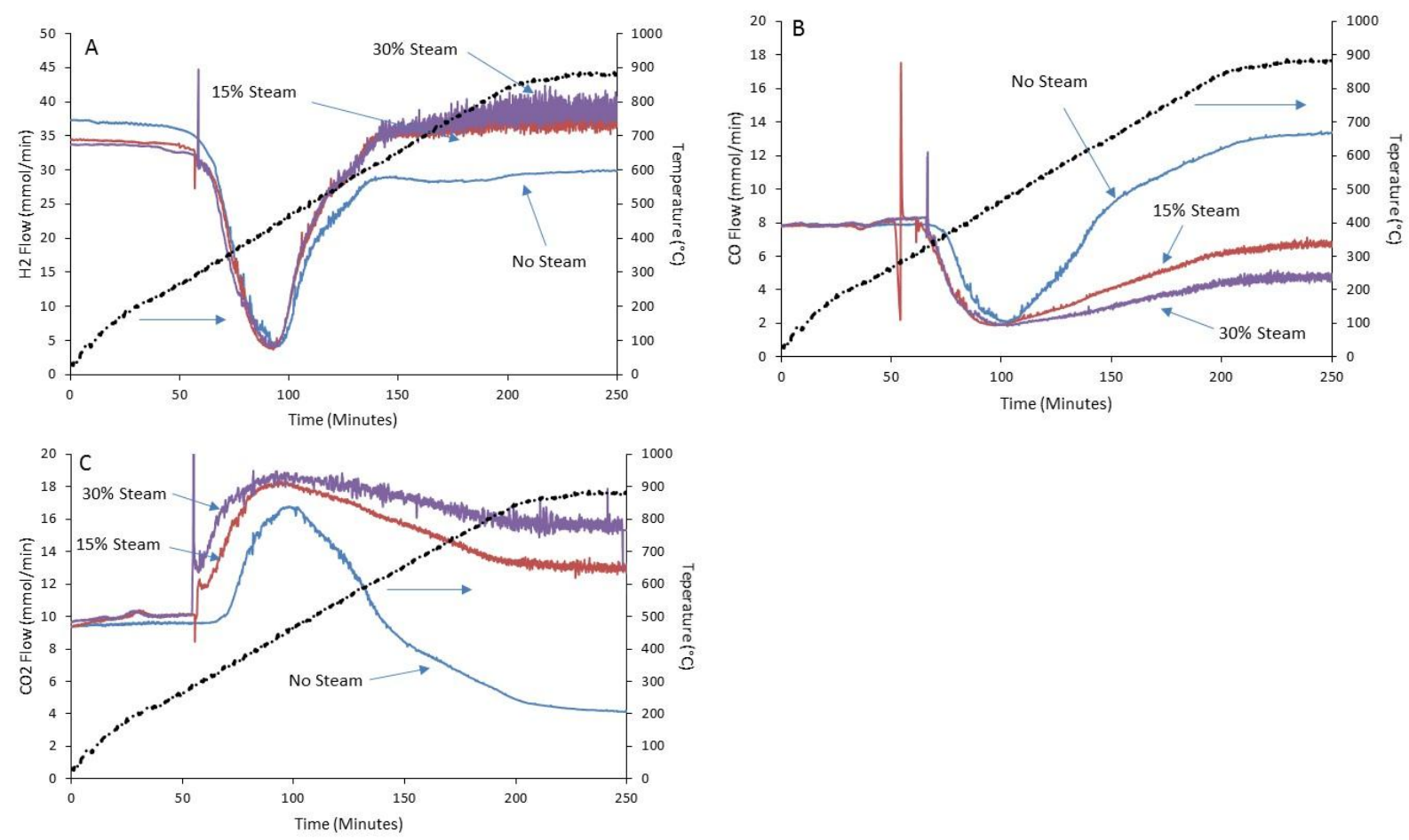

Figure 6. Product gas flow rate during the temperature ramp $\left(\mathrm{RT}-850^{\circ} \mathrm{C}\right)$ of the copper ferrite oxygen carrier in the presence of a simulated Illinois \#6 synthesis gas and varying compositions of steam (300$\left.850^{\circ} \mathrm{C}\right)(\mathrm{A}) \mathrm{H} 2(\mathrm{~B}) \mathrm{CO}(\mathrm{C}) \mathrm{CO} 2$ 

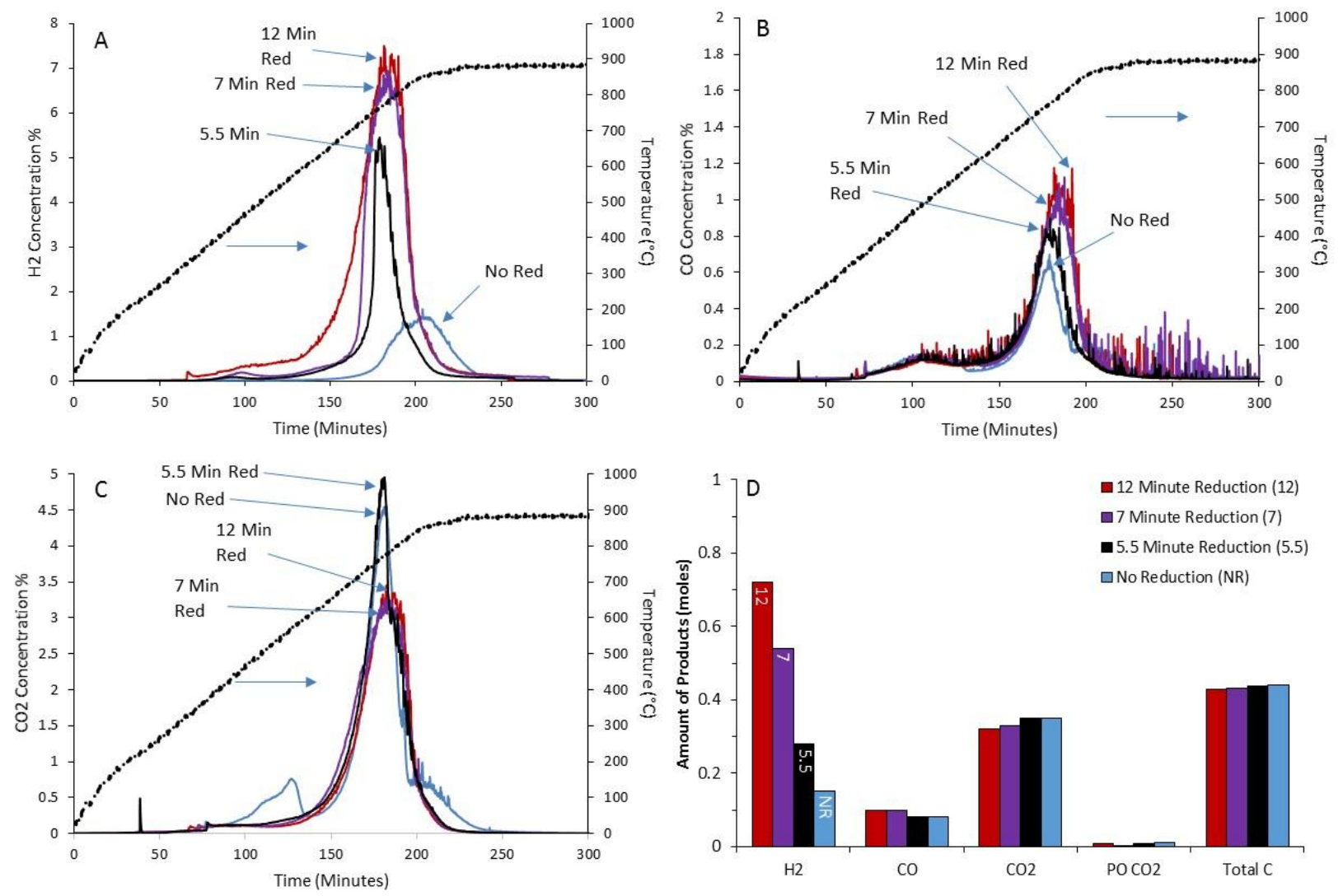

Figure 7. Product gas composition during the temperature ramp $\left(\mathrm{RT}-850^{\circ} \mathrm{C}\right)$ of reduced and unreduced copper ferrite oxygen carrier in the presence of $30 \%$ steam $\left(300-850^{\circ} \mathrm{C}\right)$ and Wyodak coal (A) H2 (B) CO (C) $\mathrm{CO} 2$ (D) Total Molar Production of Gases 

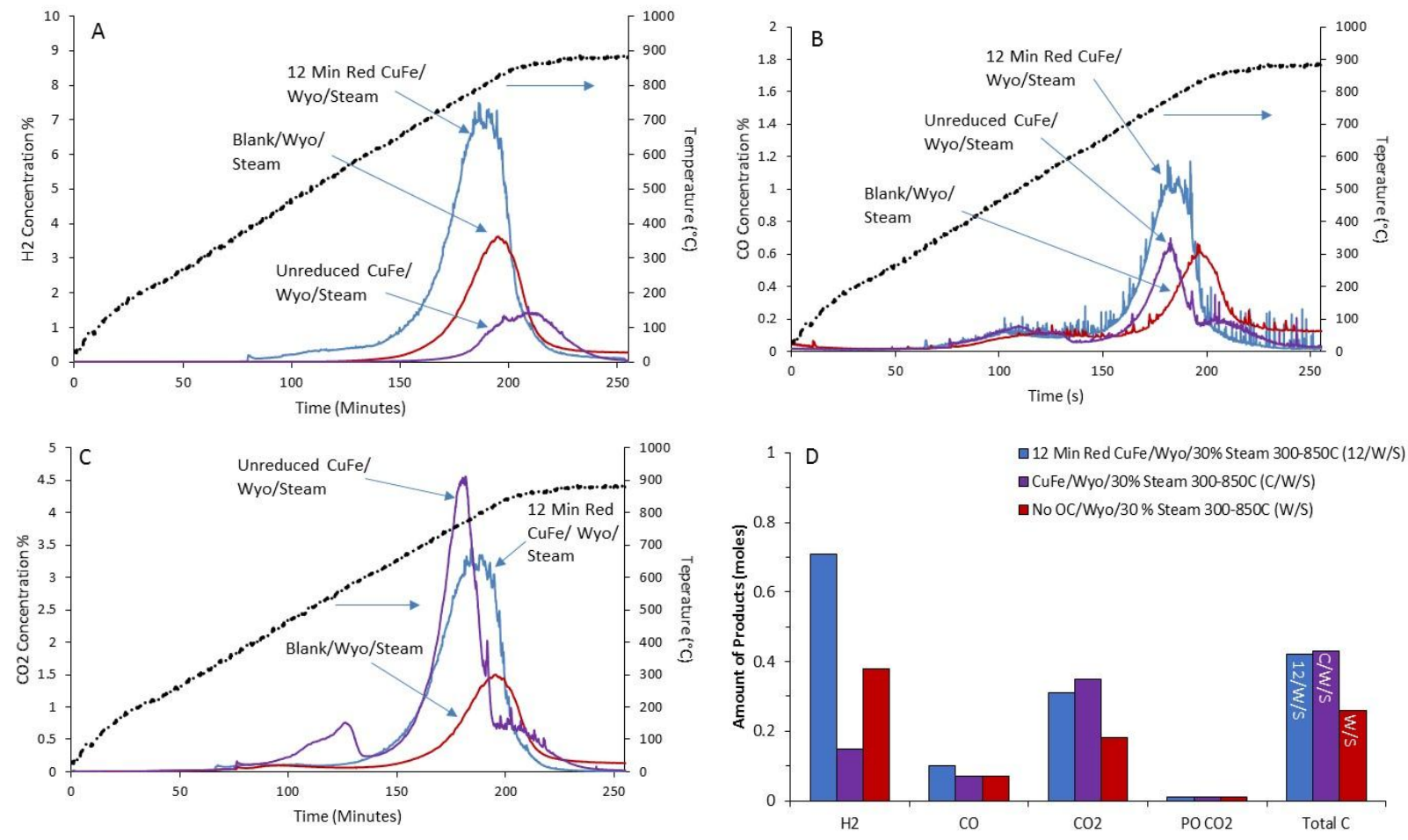

Figure 8. Product gas composition during the temperature ramp $\left(\mathrm{RT}-850^{\circ} \mathrm{C}\right)$ of reduced and unreduced copper ferrite oxygen carrier in the presence of $30 \%$ steam $\left(300-850^{\circ} \mathrm{C}\right)$ and Wyodak coal compared with the gasification of Wyodak coal in $30 \%$ Steam $\left(300-850^{\circ} \mathrm{C}\right.$ ) (A) H2 (B) CO (C) CO2 (D) Total Molar Production of Gases 

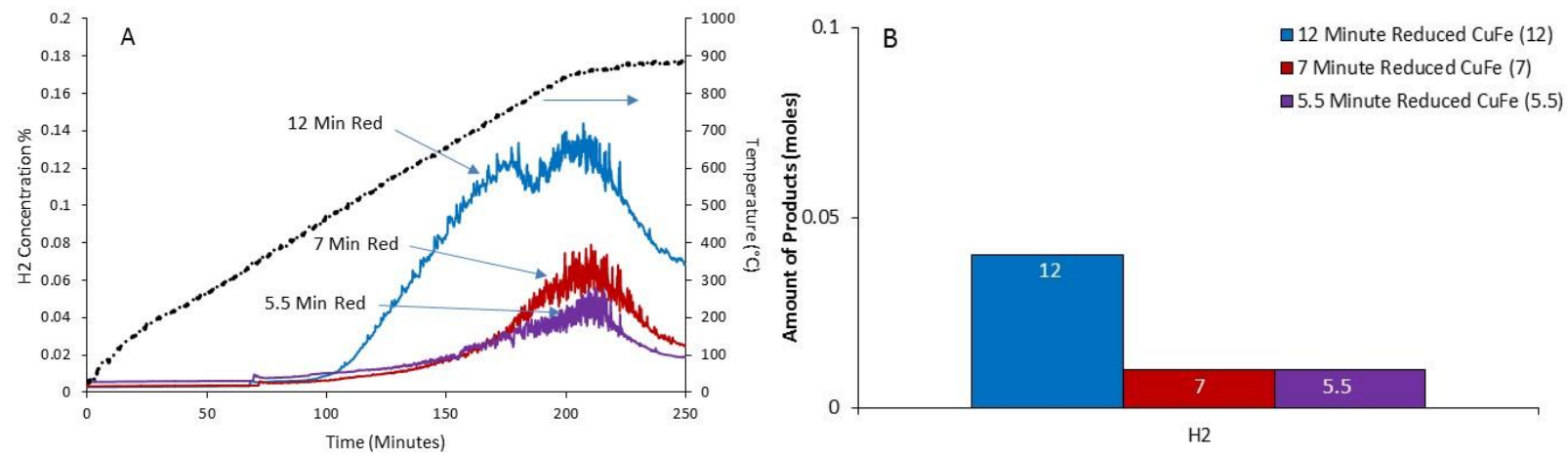

Figure 9. Product gas composition during the temperature ramp $\left(\mathrm{RT}-850^{\circ} \mathrm{C}\right)$ of reduced copper ferrite oxygen carrier in the presence of $30 \%$ steam $\left(300-850^{\circ} \mathrm{C}\right)(\mathrm{A}) \mathrm{H} 2$ (B) Total Molar Production 

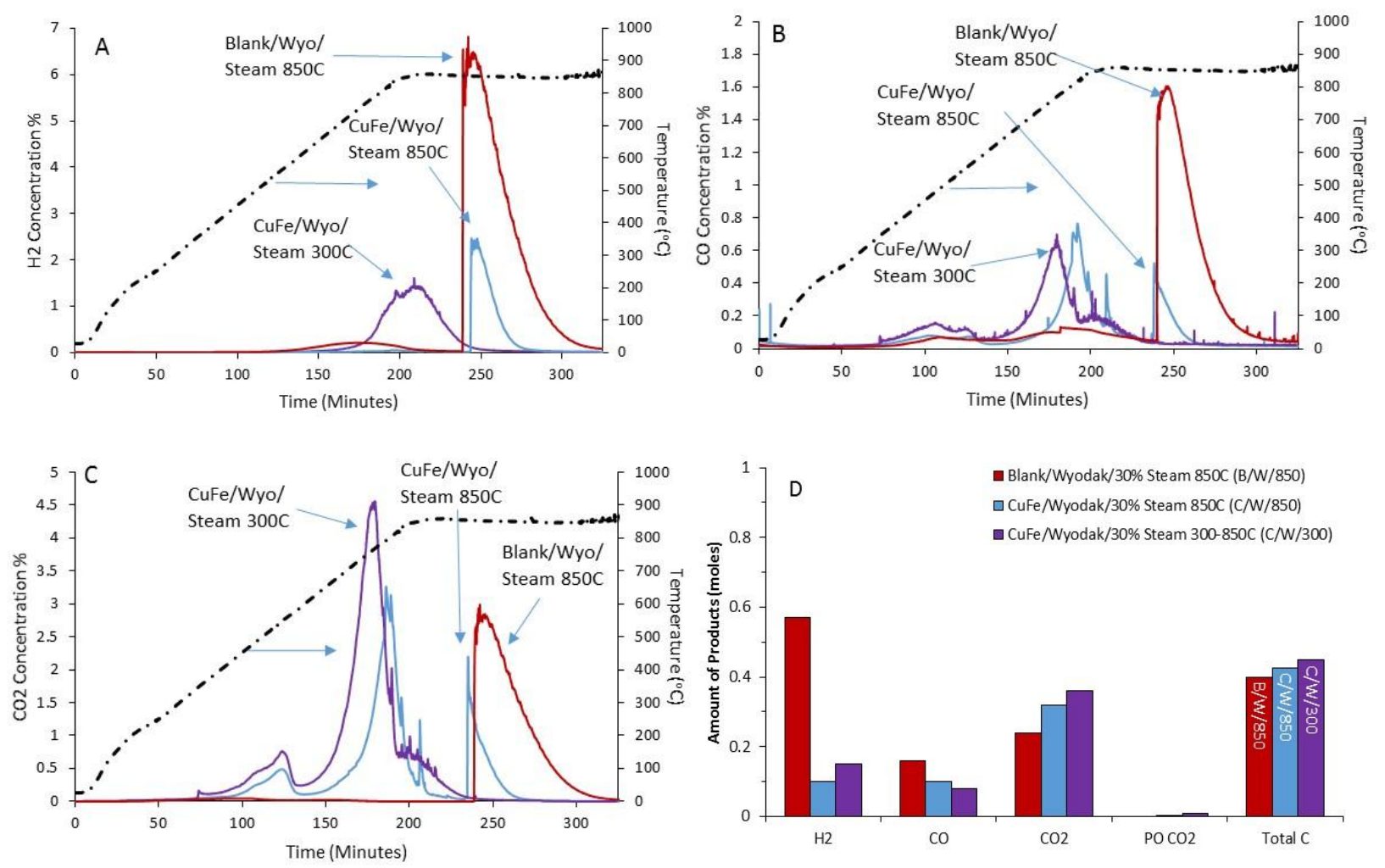

Figure 10. Product gas composition during the temperature controlled reduction $\left(\mathrm{RT}-850^{\circ} \mathrm{C}\right)$ of Wyodak coal with $30 \%$ steam addition at $850^{\circ} \mathrm{C}$ with and without the copper ferrite oxygen carrier and Wyodak coal in the presence of the copper ferrite oxygen carrier and $30 \%$ steam $\left(300-850^{\circ} \mathrm{C}\right)(\mathrm{A}) \mathrm{H} 2(\mathrm{~B}) \mathrm{CO}(\mathrm{C})$ CO2 (D) Total Molar Production of Gases 

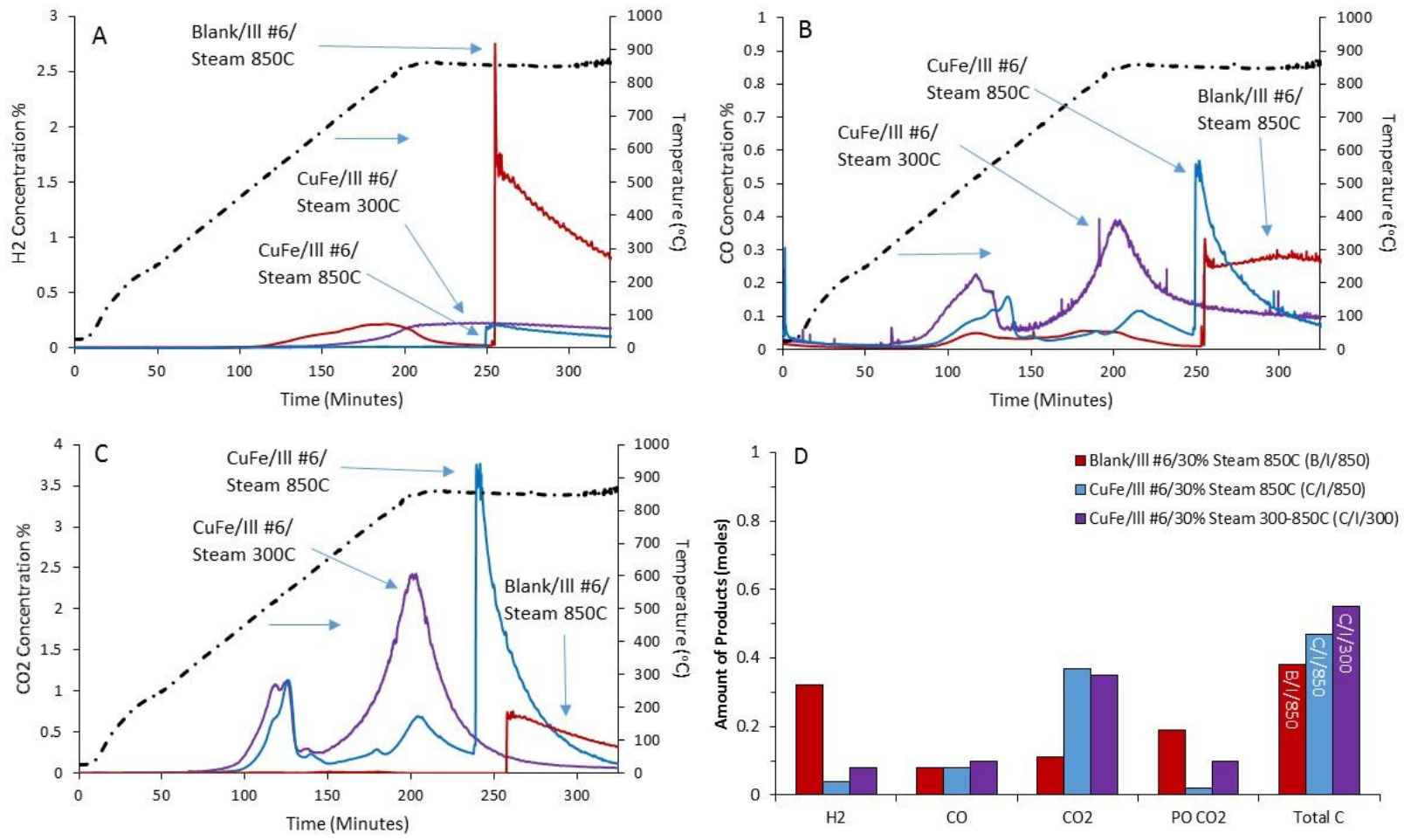

Figure 11. Product gas composition during the temperature controlled reduction $\left(\mathrm{RT}-850^{\circ} \mathrm{C}\right)$ of Illinois \#6 coal with $30 \%$ steam addition at $850^{\circ} \mathrm{C}$ with and without the copper ferrite oxygen carrier and Illinois \#6 coal in the presence of the copper ferrite oxygen carrier and $30 \%$ steam $\left(300-850^{\circ} \mathrm{C}\right)(\mathrm{A}) \mathrm{H} 2(\mathrm{~B}) \mathrm{CO}(\mathrm{C})$ CO2 (D) Total Molar Production of Gases 


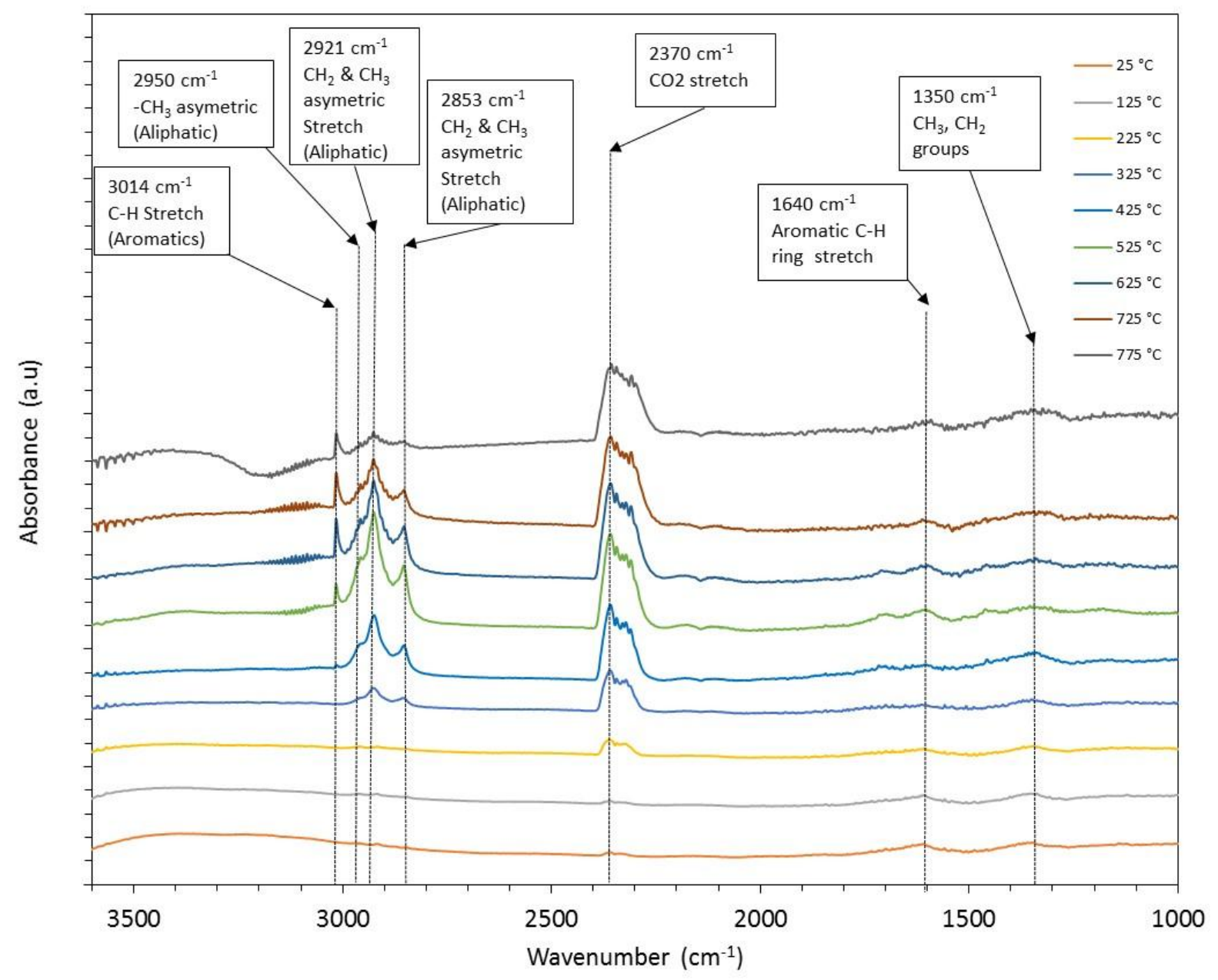

Figure 12. Diffuse reflectance infrared fourier transform spectroscopic (DRIFTS) data of Wyodak Coal during temperature ramp (Ambient $-800{ }^{\circ} \mathrm{C}$ ) 


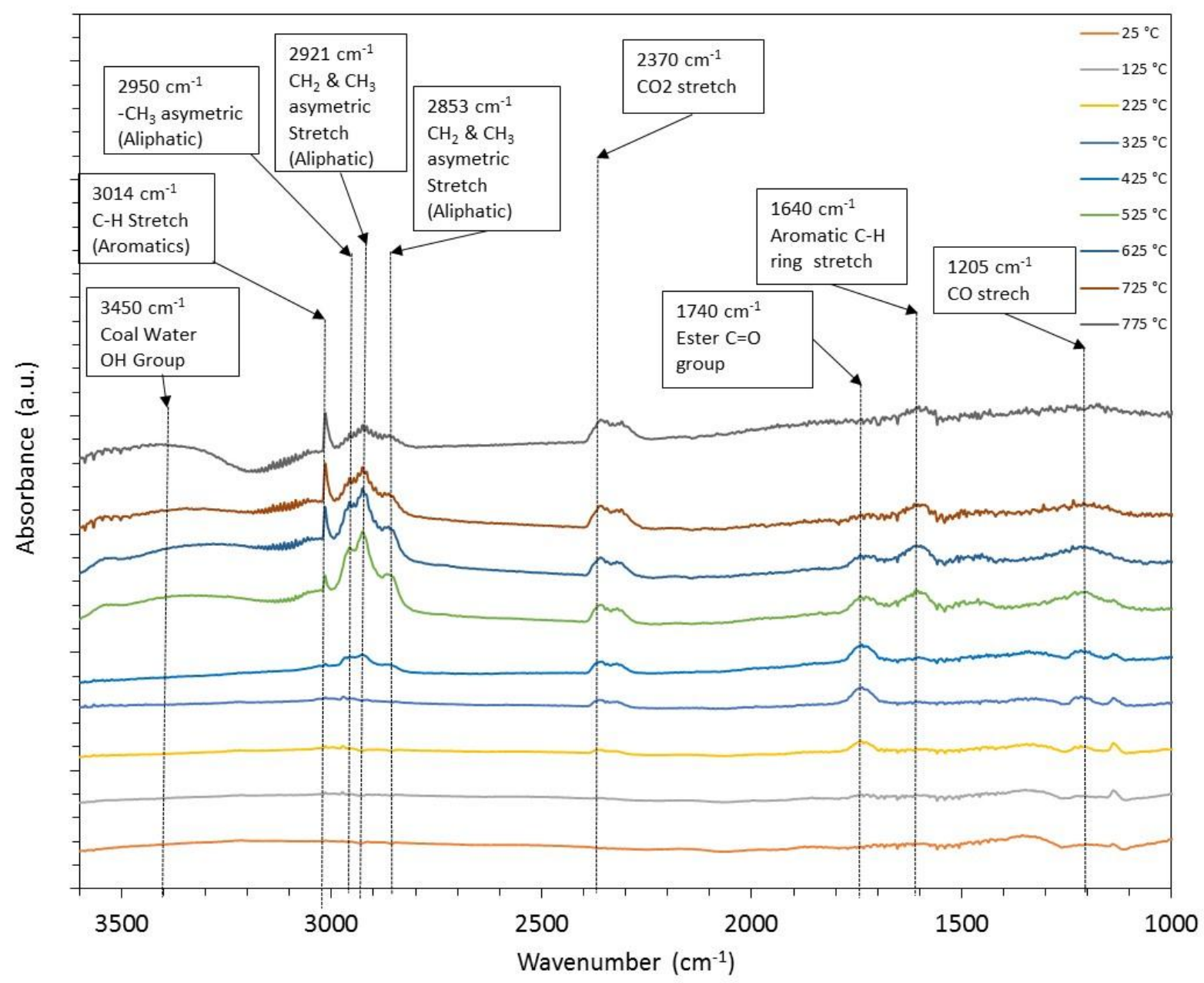

Figure 13. Diffuse reflectance infrared Fourier transform spectroscopic (DRIFTS) data of Illinois \#6 Coal during temperature ramp (Ambient $-800{ }^{\circ} \mathrm{C}$ ) 

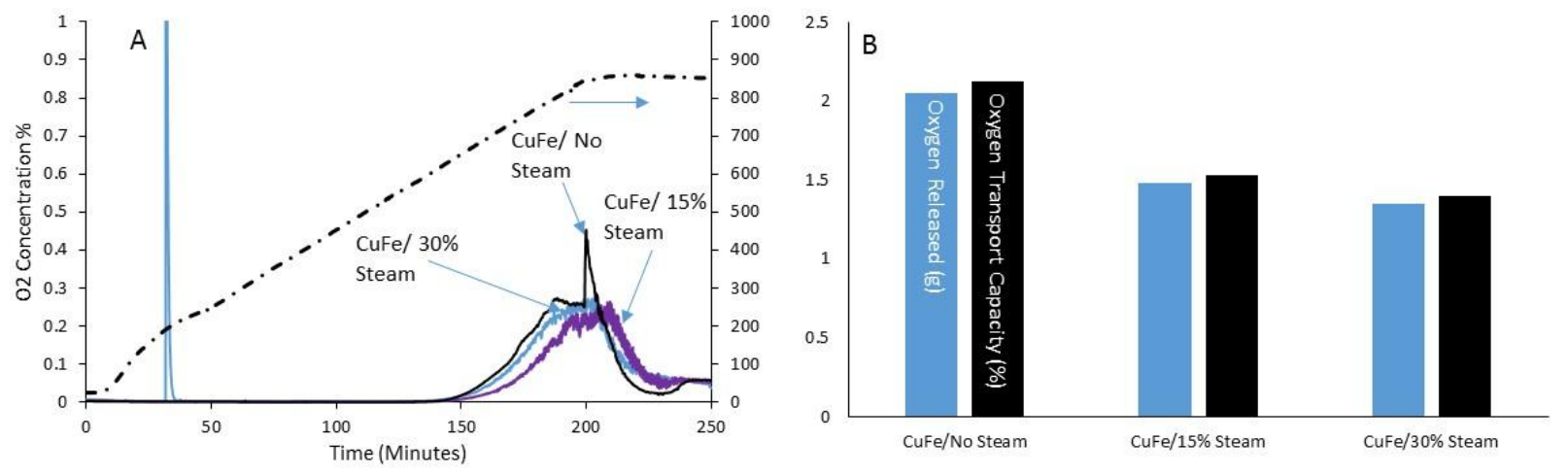

Figure 14. Oxygen uncoupling product gas composition of the copper ferrite oxygen carrier during the temperature controlled reduction $\left(\mathrm{RT}-850^{\circ} \mathrm{C}\right)$ with varying compositions of steam $\left(300-850^{\circ} \mathrm{C}\right)(\mathrm{A}) \mathrm{O} 2$ (B) Calculated Oxygen Transfer Capacity 


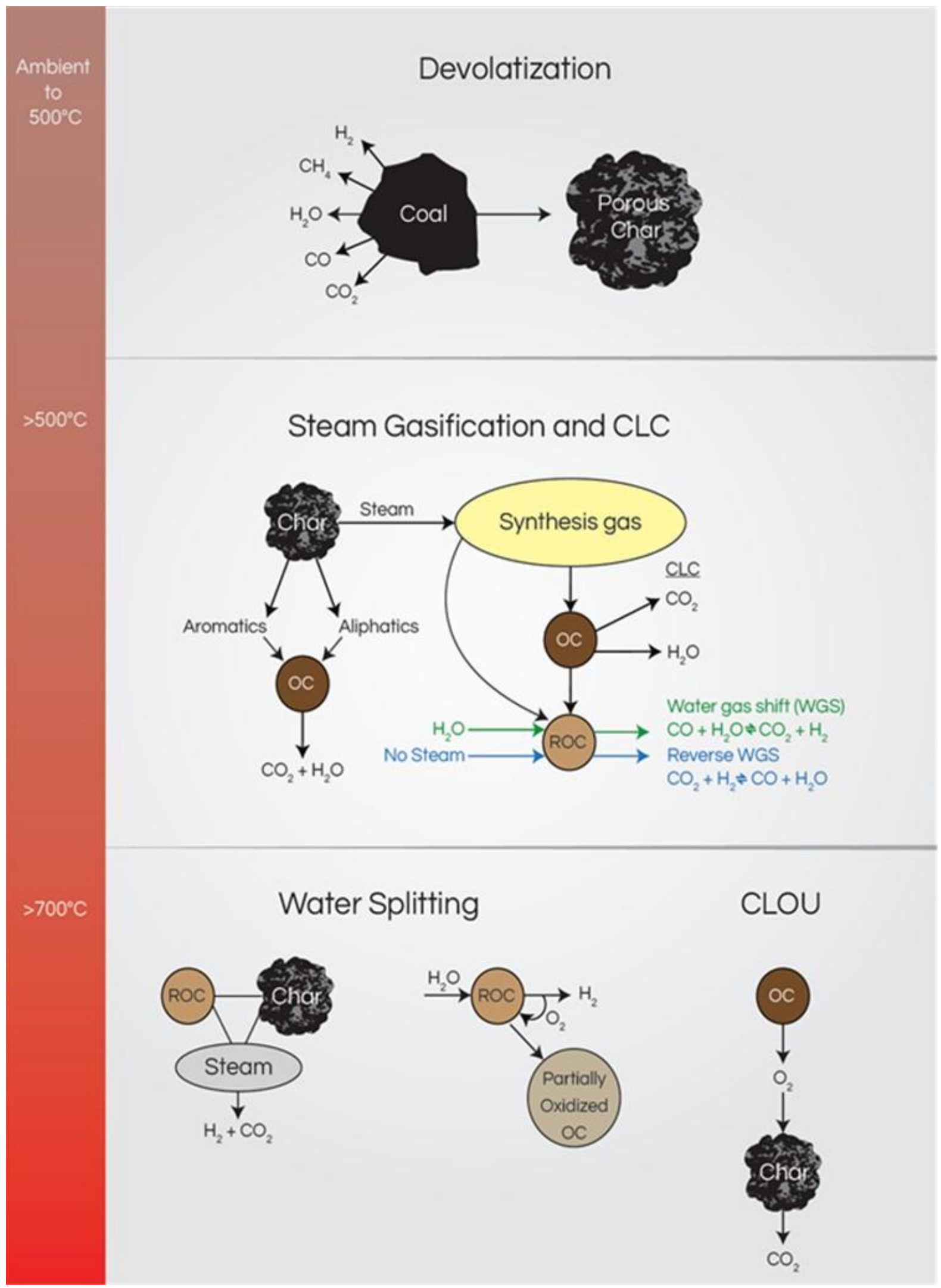

Figure 15. Flow diagram of the contributing reactions in the coal/steam/oxygen carrier system 